\title{
Characteristics of Organically Grown Compared to Conventionally Grown Potato and the Processed Products: A Review
}

\author{
Koffi Djaman ${ }^{1, * \mathbb{D}}$, Soum Sanogo ${ }^{2}$, Komlan Koudahe ${ }^{3} \mathbb{D}$, Samuel Allen ${ }^{1}$, Aminou Saibou ${ }^{4}$ and amuel Essah ${ }^{5}$ \\ 1 Agricultural Science Center at Farmington, Department of Plant and Environmental Sciences, New Mexico \\ State University, P.O. Box 1018, Farmington, NM 87499, USA; samallen@nmsu.edu \\ 2 Department of Entomology, Plant Pathology, and Weed Science, New Mexico State University, MSC 3BE, \\ P.O. Box 30003, Las Cruces, NM 88003, USA; ssanogo@nmsu.edu \\ 3 Biological and Agricultural Engineering Department, Kansas State University, 1016 Seaton Hall, 920 N. \\ Martin Luther King Jr. Drive, Manhattan, KS 66506, USA; koudahek@ksu.edu \\ 4 Department of Crop and Soil Sciences, Washington State University, P.O. Box 646420, \\ Pullman, WA 99164, USA; aminou.saibou@wsu.edu \\ 5 San Luis Valley Research Center, Department of Horticulture and Landscape Architecture, Colorado State \\ University, 0249 E Rd. 9 N, Center, CO 81125, USA; samuel.essah@colostate.edu \\ * Correspondence: kdjaman@nmsu.edu; Tel.: +1-505-960-7757
}

Citation: Djaman, K.; Sanogo, S.; Koudahe, K.; Allen, S.; Saibou, A.; Essah, S. Characteristics of Organically Grown Compared to Conventionally Grown Potato and the Processed Products: A Review. Sustainability 2021, 13, 6289. https:// doi.org/10.3390/su13116289

Academic Editor: Sara Bosi

Received: 22 April 2021

Accepted: 26 May 2021

Published: 2 June 2021

Publisher's Note: MDPI stays neutral with regard to jurisdictional claims in published maps and institutional affiliations.

Copyright: (c) 2021 by the authors. Licensee MDPI, Basel, Switzerland. This article is an open access article distributed under the terms and conditions of the Creative Commons Attribution (CC BY) license (https:// creativecommons.org/licenses/by/ $4.0 /)$.
Abstract: Interest in organic foods is increasing at a moment when humanity is facing a range of health challenges including the concern that some conventionally produced foods may pose possible adverse effects on human and livestock health. With the increasing human population, intensive production is increasingly trending towards high-input systems that aim to close yield gaps, increase crop yields, and develop new crop varieties with higher yield potential and tolerance to biotic and abiotic stresses, all within the context of incorporating specific traits to satisfy consumer demand. Potato (Solanum tuberosum L.) is one of the most consumed foods under different cultural diets; however, its production faces some challenges related to soilborne diseases, marketable yield and quality, sugars and dry matter content of the produced tubers, tuber content in terms of nitrate, minerals, vitamins, bioactive compounds, and antioxidants, and consumer appreciation regarding the sensory characteristics of tubers and processed products. Different studies have been investigating some of these challenges, with sometimes straightforward and sometimes conflicting results. This variability in research results indicates the general non-transferability of the results from one location to another under the same management practices in addition to differences in plant material. This review compares some characteristics of raw or boiled potato and processed products from potato tubers grown organically and conventionally. Ideally, such information may be of benefit in decision making by consumers in their dietary choices, by potato growers in their selection of crop management practices, and by scientists looking at potential areas for future research on potatoes.

Keywords: organic; conventional; potato; quality; disease

\section{Introduction}

Potato (Solanum tuberosum L.) is the fourth-largest crop produced worldwide after rice, wheat, and maize at a total annual production of 370, 504, 766, and 1150 million tons for potato, rice, wheat and maize, respectively [1]. Potato is adapted to a large range of geographical environments and climates [2]. Potato is consumed by humans under many different preparations-boiled, baked, fried, snack, chips, starch-and is a significant source of carbohydrates [3,4], protein [3,5,6], minerals [6], vitamin C [4], and phenolic compounds [6]. Potato crop is very sensitive to water stress [7-9], nitrogen fertilizer deficiency, and is subject to a wide variety of disorders and diseases. Aboveground disorders and diseases include early blight (Alternaria solani), late blight (Phytophthora 
infestans), Fusarium dry rot (Fusarium spp.), black dot (Colletotrichum coccodes), potato virus Y, black leg (Pectobacterium spp.), aerial stem rot (Pectobacterium carotovorum subsp. carotovorum), ring rot (Clavibacter michiganensis subsp. sepedonicus), and alternaria brown spot (Alternaria alternate)]. Physiological disorders include growth cracks, knobs, misshapes, hollow heart, and brown center, among others. Soilborne diseases include Rhizoctonia canker and black scurf (Rhizoctonia solani), common scab (Streptomyces scabiei), powdery scab (Spongospora subterranea f. sp. subterranean), white mold (Sclerotinia sclerotiorum), silver scurf (Helminthosporium solani), pink rot (Phytophthora erythroseptica), Verticillium wilt (Verticillium dahlia), pythium leak (Pythium spp.), and brown rot (Ralstonia solanacearum)]. All of these disorders and diseases can tremendously impact tuber yield and the organoleptic quality of the harvested tubers and the processed products.

Different factors affect the quality of the potato tubers. Nitrogen availability to potato plants is critical to plant growth and development, tuber yield, and quality. Nitrogen form and source are one of the main differences between conventional and organic potato production [10-14]. In addition, to control the numerous potential diseases and stabilize yield in potatoes, commercial growers apply a strict package of pesticides and high rate of nitrogen fertilizer $[3,13,15-17]$. Some undesirable residues can be accumulated in the potato tubers [18] and the soil [19] under conventional farming that can potentially affect human and animal health [20], and organic foods are therefore generally assessed as being healthier and of better taste than conventionally grown crops [21,22].

The taste and bitterness are the main sensory properties of the boiled potato tuber, and the texture, color and oil content, and crispiness are the main quality parameters of fried potatoes [23-26]. Moyano et al. [27] found a direct relationship between potato's specific gravity, total solids content, starch content, cell size, and surface area and pectin and potato texture. For the processed product, like potato chips, a very crispy texture is expected as crispness is an indicator of freshness and high quality [24,28-30]. Moreover, the color of the fresh, boiled or fried potatoes is considered one of the most important defining qualities caused by factors such as sugar content of potato tubers, storage temperature and duration, potato genotype, high soil moisture late in the growing season, low specific gravity of potato tuber, and enzymatic browning [31-35]. Particularly in fried potatoes, the browning process is the result of the Maillard reaction that is directly linked with the reducing sugars content and amino acids or proteins at the surface, and the temperature and duration of frying [36,37].

For the present review, we compared some characteristics of the organically grown potato tubers to the conventional ones. We have considered only side-by-side comparative studies that include both organic and conventional farming practices, in order to exclude some extraneous information that might not necessarily be the impact of the organic farming but the effects of uncontrolled factors. The main characteristics in our review focus on disease pressure on the potato plant and tubers, potato tuber total and marketable yields, specific gravity and dry matter content, sugar and starch contents of potato tubers, nitrate content of potato tubers, bioactive compounds and antioxidant contents in potato tubers, mineral and vitamin content, and the sensory characteristics of the potato tubers.

\section{Weed and Pest Management in Potato}

Weeds are a threat to any cultivated crop and negatively impact crop production as they compete with the planted crop for light, nutrients, water, and space. They induce quantity and quality losses of the yield and ultimately decrease the net return of the production system with increased production costs. Potato cultivars with a strong, erect shoot growth habit with shorter stems, more branching, and a denser and taller canopy in the early stages of plant growth may be less susceptible to weed interference than cultivars with less lofty plant habit [38-40]. Commercial potato growers follow rigorous herbicide application schedules throughout the conventional potato growing season and apply different pesticides. While conventional potato often starts by soil fumigation, organic potato often relies on the biofumigation provided by cover crops such as those of the Brassicacea 
family. Boydston [41] reported that weeds should be managed in a holistic, intentional, and proactive manner if no herbicide is considered. Under organic farming, crop rotation, cover crop selection, planting pattern and timing in addition to healthy and appropriate seed material are the main aspects to be considered for successful weed management. Some specific plants considered as cover crops such as sudangrass and different species of Brassica have been used as a green manure and biofumigant to reduce nematode populations preceding potatoes and weed emergence [42-44]. Cover crops that have reportedly suppressed weeds through direct competition or release of allelopathic compounds during decomposition of residues include rye, oats, barley, rapeseed, mustards, sorghum-sudangrass hybrids, and buckwheat [42,45-56]. Mustard foliage and seeds contain glucosinolate compounds that upon hydrolysis produce isothiocyanates, which act as natural bio-fumigants [57-59]. In addition, multiple, well-timed shallow cultivations or heat-flaming can eliminate many early season weeds and the application of new technologies for detecting crop rows and weeds coupled with precision cultivation, flaming, and application of nonselective organic herbicides are being developed and hold promise to reduce the need for labor-intensive hand weeding [41]. Cover crops are planted by both organic and conventional potato growers for multiple objectives: Nitrogen fixation, soil hydraulic properties improvement, disease and nematode suppression, adding more organic matter to the soil, nutrients reclamation, etc. [51,56,60-62]. With cultivation as the only weed management practice in potato production, weed density increased with reduction in tuber yield compared to hand weeding or herbicide application [63,64]. VanderZaag [65] reported that weekly scouting of all fields to determine economic thresholds before spraying and the reliance on weekly newsletters informing about the status of pests and diseases offers significant, environmentally friendly approaches for sustainable weed, pest, and disease management across the potato field. The use of neonicotinoid chemistry as a seed tuber treatment greatly reduced the need to spray insecticide, especially for Colorado potato beetle control, and the amendment with cattle or swine manure led to better crop health and reduced the need for pest and disease treatments [65]. Herbicide selection, herbicide combinations, and application rates and timing determine the effectiveness of the method in weed management [40,66-68]. Barbaś et al. [40] found that the chemical method of controlling weeds was the most effective weed control method over a combination of mechanical methods in potato production. However, the combination of metribuzin and rimsulfuron+SN oil as a potato pre-emergence tool was more effective than the other meribuzin, ethoxylated isodecyl alcohol $0.1 \%$, fluazyfop-P butyl, and SN oil combinations.

\section{Nutrient Management}

Potatoes are a special crop, and not only does the organic production system affect the crop plant growth and yield, but the tuber quality during cold storage is also affected by the particular production system. Organic farming faces many challenges such as proper nutrient management, weeds, diseases, and insect pest control [69]. Both organic and conventional systems have adopted cover cropping to improve soil organic matter content and improve soil quality. Bio-fertilizers derived from microorganisms are an alternative to chemical and organic fertilizers. El-Sayed et al. [70] compared mineral fertilizers (at a rate of $285.6 \mathrm{~kg} \mathrm{~N}+178.5 \mathrm{~kg} \mathrm{P} \mathrm{P}_{2} \mathrm{O}_{5}+357 \mathrm{~kg} \mathrm{~K} \mathrm{~K}_{2} \mathrm{O} / \mathrm{ha}$ ) to a combination of bio-fertilizers consisting of nitrogen fixers (Azospirillum brasilense and Azotobacter chroococcum), P-dissolving bacteria (Bacillus megaterium and vesicular-arbuscular mycorrhiza), and K-dissolving bacteria (Bacillus cereus) plus different rates of compost on potatoes. They found significant increases in the total and marketable yield of potato from plots treated with $50 \%$ of the recommended mineral fertilizers plus $23.8 \mathrm{t}$ / ha compost with or without bio-fertilizer as well as from plots that received compost at $35.7 \mathrm{t} / \mathrm{ha}$, compared with plots treated with full dose of mineral fertilizer plus $11.9 \mathrm{t} / \mathrm{ha}$ compost (control). However, the conventional fertilizer showed significantly higher weight loss of potato tubers during cold storage than all other treatments [70]. Mycorrhiza and Azospirillum as bio-fertilizers were found to reduce nitrate and nitrite contents of potato tubers [71,72]. Mycorrhizal potato plants were reported to 
show improved growth and development, pathogen resistance, and productivity compared to non-inoculated potato plants [73-77]. Khosravifar et al. [78] inoculated potato plant with Claroidoglomus etunicatum and Rhizophagus intraradices and found that $R$. intraradices increased tuber yield by $32.5-36.0 \%$ compared to non-inoculated control plants with a maximum root colonization percentage of $54.2 \%$. Arbuscular mycorrhizal fungi are found to increase tolerance of potato plants to drought, salinity, and disease by facilitating water and nutrient acquisition and by improving overall soil structure [77].

Carter et al. [79] reported that the application of compost once in a 3-year potato rotation was beneficial for both soil physical and biological properties, and for potato productivity. However, due to the limited viability of compost and/or organic fertilizers in many locations and their low nitrogen content [80], organic fertilizer may be challenging, and more emphasis should be given to cover cropping in addition to bio-fertilizers that colonize the soil under organic production in humid and sub-humid climates. The bio-fertilizers are constituted with microorganisms which solubilize the unavailable forms of inorganic-P [81] and potassium rock through the production and secretion of organic acids [82]. The leguminous cover crops are associated with the nitrogen-fixing bacteria Azotobacter spp., which are known to produce different growth hormones, vitamins, and siderophores. Azotobacter is capable of converting nitrogen into ammonia, the form of nitrogen that can be taken up by plants [83]. Jen-Hshuan [84] reported that Azotobacter spp. can produce antifungal compounds to fight against plant pathogens. Rees et al. [85] reported that in-season fresh poultry manure amendment increased potato total yield compared to the fall application [86]. Lynch et al. [87] reported the commercial hog manuresawdust compost (CP) and pelletized poultry manure (NW) applied at 300 and $600 \mathrm{~kg}$ total $\mathrm{N} /$ ha positively affect potato tuber yield and potato plant $\mathrm{N}$ uptake $(112 \mathrm{~kg} \mathrm{~N} / \mathrm{ha})$ under non-limiting soil moisture conditions. Fahmy et al. [88] found that pulp-fiber residue compost amendment increased potato plant-available phosphorus and potassium and the tuber yield was increased under supplementary irrigation while no change was observed in a rainfed setting compared to the non-amended plot. Green manure management and the recycling of organic materials may be a valid alternative to the conventional synthetic fertilizer-based management system for sustainable potato production, sustaining tuber yield without enhancing potential environmental risks due to $\mathrm{N}$ leaching [89]. Drakopoulos et al. [90,91] investigated solid cattle manure, lucerne pellets, grass/clover silage amendments on crop performance, and nitrogen utilization of organic potato and found that plant-based fertilizers enhanced nitrogen utilization in terms of apparent nitrogen recovery compared to animal-based manures, and the lucerne pellets resulted in the highest yield regardless of the tillage practices. Wilson et al. [92] reported that soil amendments with diverse wood waste and manure compost products resulted in a small increase in plant $\mathrm{N}$ availability in small plots experiments. The immature products resulted in net $\mathrm{N}$ immobilization, the composts high in $\mathrm{K}$ increased plant $\mathrm{K}$ availability with non-significant effects on tuber yield.

\section{Potato Disease Occurrence and Intensity}

Disease management is a serious challenge and threat to organic potato management and disease pressure depends on crop physiology and nutrient availability that confers plant tolerance to disease stressors [93-97]. Late blight, caused by Phytophthora infestans, is commonly thought to be the factor most limiting yield under organic practices [69]. Common scab (caused by Streptomyces scabies), silver scurf (caused by Helminthosporium solani), and soft rot (caused by Pectobatcerium sp. and Dickeya sp.) may be detrimental to organic production systems. Organic farming relies on the agricultural practices to reduce and/or control diseases instead of applying chemical pesticides (Table 1). Larkin and Halloran [54] indicated that disease levels and crop production are influenced by crop management practices. Crop rotation plays a tremendous role in maintaining potato disease incidence at controllable levels. Through a process known as biofumigation, plants within the Brassicacae family produce glucosinolates, which break down into volatile compounds 
that are toxic to several plant pathogens [50,58,59,98-102]. Tein et al. [103] found potato common scab more severe under organic farming compared to the conventional farming during two seasons out of three. Conversely, the number of tubers infected by silver scurf was lower under organic farming while there was no significant difference between the farming system with regard to potato soft rot infection [103]. Tein et al. [103] found that the application of cattle manure in addition to catch crops increased the severity of silver scurf and common scab. However, the use of green and animal manures under organic farming rarely has a disease-increasing effect on soilborne diseases infection and severity $[50,104]$. Some studies have shown that the application of cattle manure overall increases the incidence of soilborne diseases [103,105,106]. Moore et al. [107] pointed out that manure provides optimum conditions for common scab development by altering soil $\mathrm{pH}$ level. Tein et al. [103] investigated the effect of management practices on potato tuber diseases such as common scab (Streptomyces spp.), silver scurf (Helminthosporium solani), dry rot (Fusarium spp.) and soft rot (Pectobacterium spp.) and found that the organic systems had significantly more tubers ( 39\%) infected with common scab (surface cover $4-15 \%$ ) than in conventional systems $(\sim 25 \%)$, fewer tubers infected with silver scurf compared to all conventional farming systems, less tubers infected with dry rot in organic systems compared to the conventional systems, and the soft rot infections were not influenced by farming systems. Bernard et al. [106] reported rapeseed rotation reduced all observed soilborne diseases such as stem canker, black scurf, common scab, and silver scurf by 10 to $52 \%$ under organic farming.

Deja-Sikora et al. [108] investigated the effect of joint Potato Virus Y infection and mycorrhizal colonization by Rhizophagus irregularis on growth traits of the host potato plant and found that the viral particles were concentrated in the leaves but decreased the root growth, and the infection with PVY evoked prolonged oxidative stress reflected by increased level of endogenous $\mathrm{H}_{2} \mathrm{O}_{2}$ and alleviation of oxidative stress in PVY-infected host plants by a substantial decrease in the level of shoot- and root-derived $\mathrm{H}_{2} \mathrm{O}_{2}$ with asymptomatic growth depression.

Organic farming heavily relies on crop rotations and improved cropping systems incorporating management practices associated with soil health management (crop rotation length, cover crop species choice, and green manures, organic matter amendments, and minimum tillage). Larkin et al. [56] found that disease suppression practices, which included disease-suppressive green manures and cover crops, produced the highest yields compared to soil improvement, soil conservation, and status quo practices representing yield increase from 11 to $35 \%$. The disease suppression system consisted of a three-year rotation with the disease-suppressive Brassica "Caliente 119", Mustard Blend (blend of oriental and white mustard seeds, Brassica juncea L. and Sinapis alba L.) grown as a green manure, followed by a fall cover crop of rapeseed (Brassica napus L." Dwarf Essex") in the first year [56]. In the second year, a disease-suppressive sorghum-sudangrass hybrid (Sorghum bicolor $x$ S. bicolor var. sudanense) was grown as a green manure, followed by a fall cover crop of winter rye (Secale cereale L.), with potato in the third year. This combination was observed to improve disease control in potato, with yield advantage. These organic management practices have been shown to significantly affect soil chemical, physical, and biological properties $[109,110]$, as well as reduce soilborne diseases and increase crop productivity [111]. The use of Brassica spp. and sudangrass cover crops preceding potato planting reduces the pressure of the soilborne diseases on potato plant and the tuber [54,56,112,113]. The mechanism of action of the disease-suppressive crops used involves biofumigation, the breakdown of plant metabolites in soil to produce volatile toxic compounds that can reduce populations of weeds, nematodes, and plant pathogens [50,100,111,114,115]. In this regard, Brassica species may change the soil microbial communities besides the bio-fumigation potential and reduce the soilborne diseases $[50,115,116]$. 
Table 1. Impact of different cover crops and crop rotation, compost, and biostimulants on soilborne diseases and potato tuber yield.

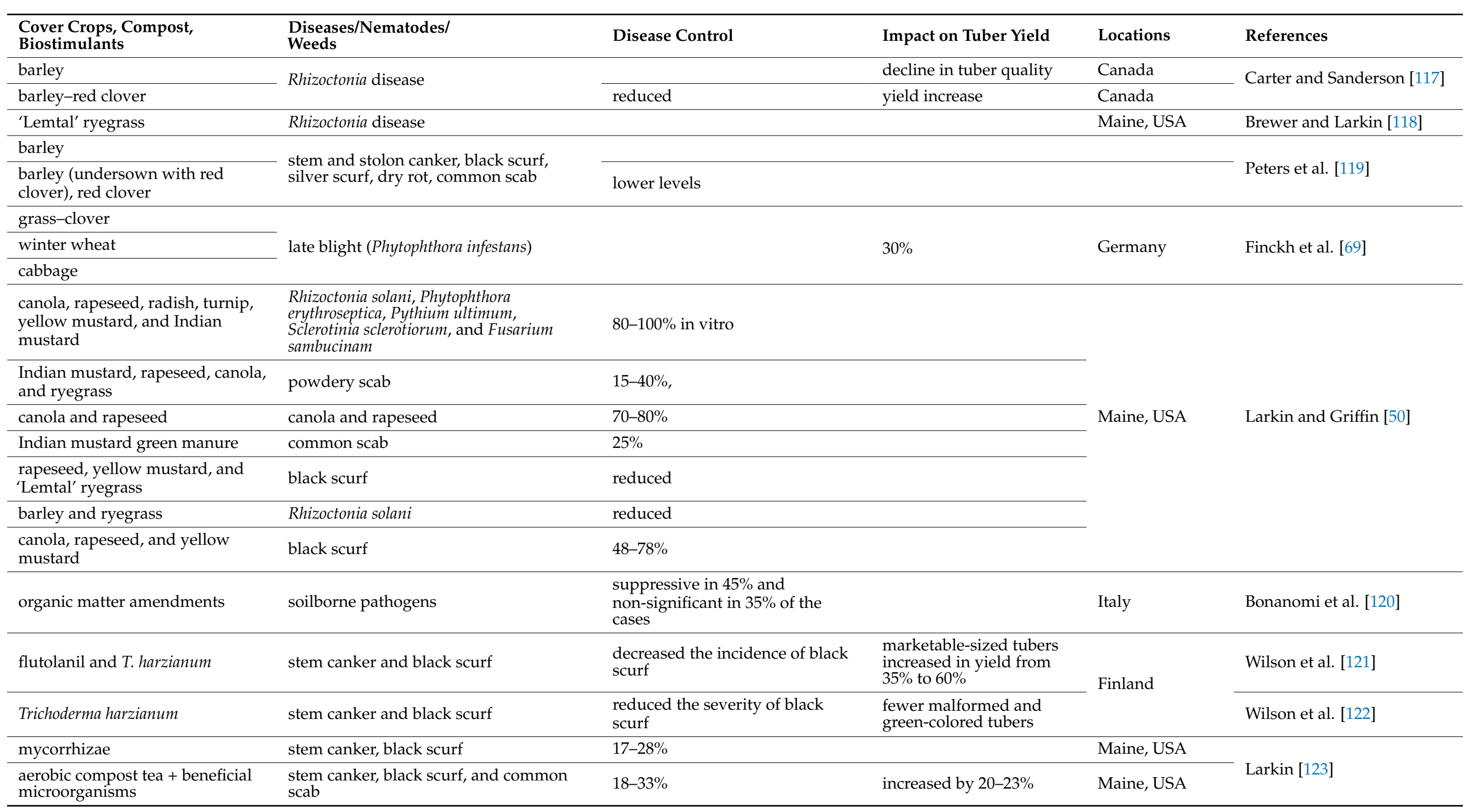


Table 1. Cont.

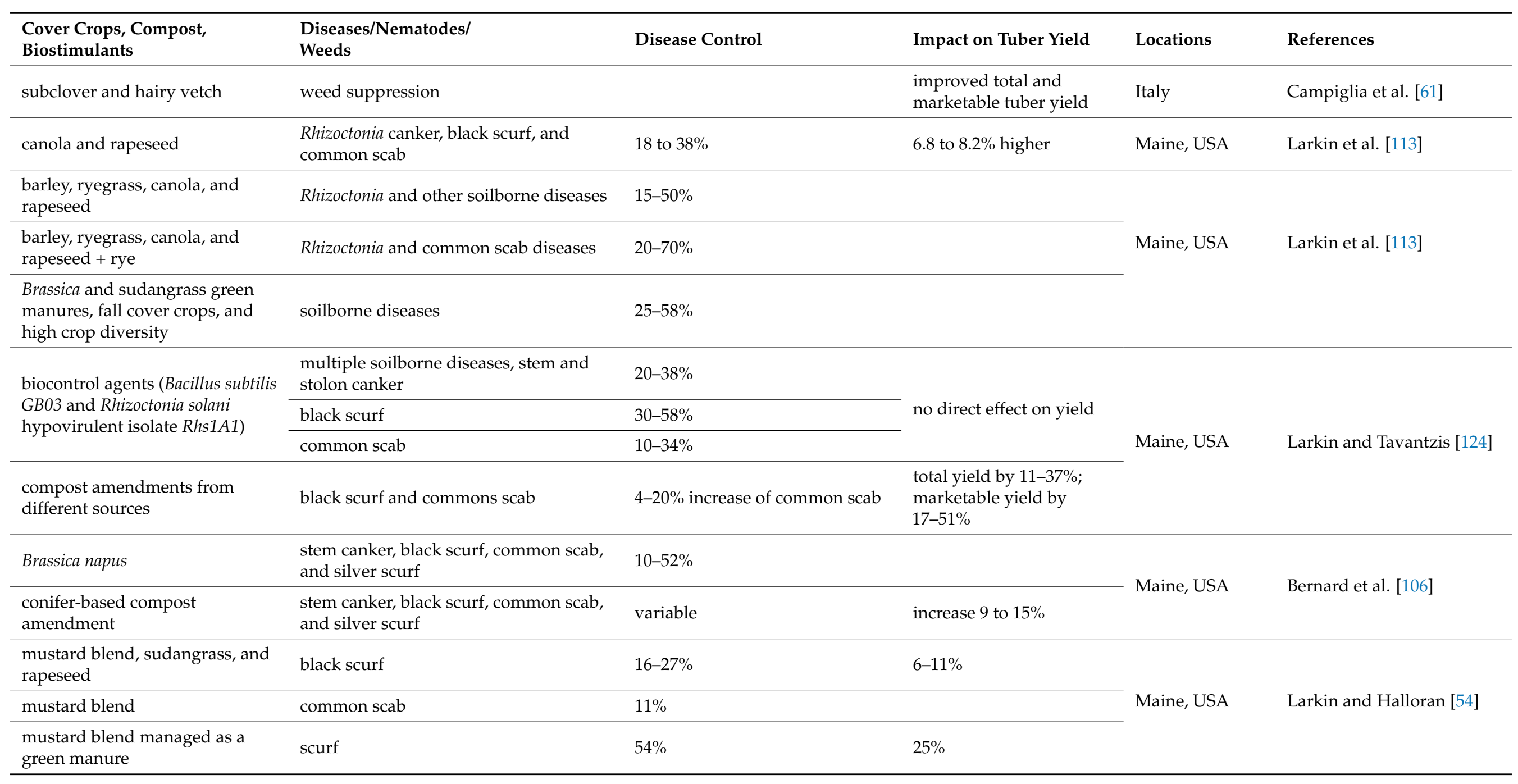


Table 1. Cont.

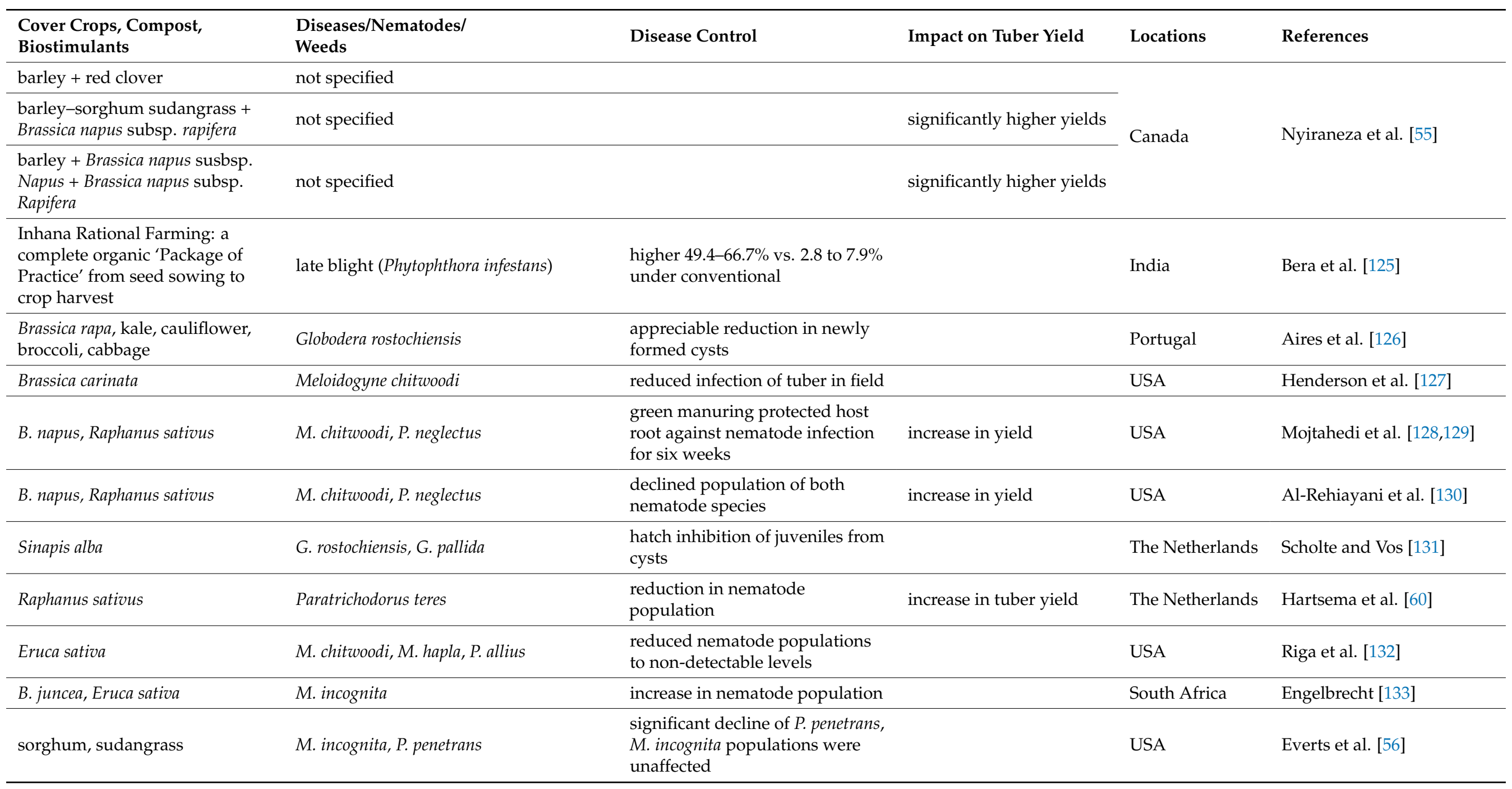


Table 1. Cont

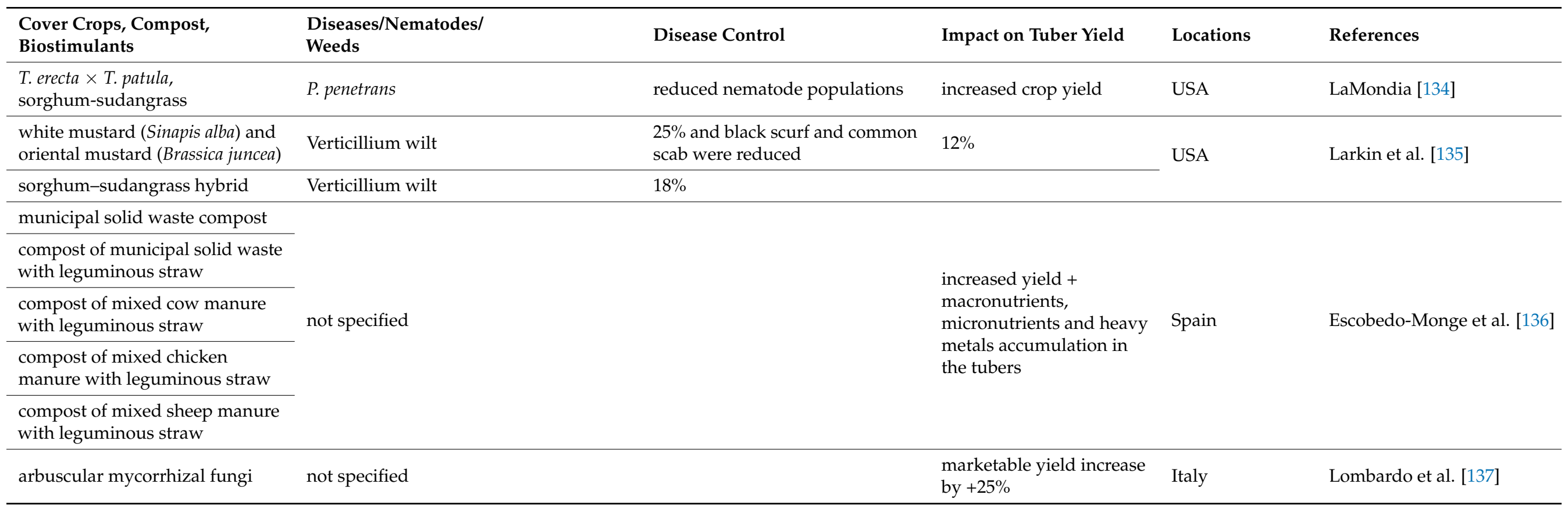




\section{Total Tuber Yield and Marketable Yield}

Potato under organic production is subjected to different pests, diseases and limited available nutrients and consequently produces lower tuber yield compared to the conventionally grown potato (Tables 1 and 2) [12,69,138-144]. Synthetic fertilizers, pesticides, and other non-organic inputs are not allowed under organic production, which infers challenges in nutrient and pest management under organic farming than conventional systems with lower marketable potato tuber yield in organic production $[69,85,145,146]$. In various studies, the yield of organically grown potato tubers is lower compared to the yield of the conventionally grown potato by $5-40 \%$ [3,147-152]. Brazinskiene et al. [153] reported potato yield under conventional production to be double the equivalent yield under organic production of five Lithuanian potato varieties (VB Venta, Goda, VB Liepa, VBRasa and VB Aista). Similarly, Kazimierczak et al. [154] reported lower tuber yield of eight potato cultivars (Mazur, Justa, Lawenda, Lech, Tacja, Laskana, Otolia, Magnolia) grown under organic system compared to conventional system. Clark et al. [138] reported that limitations in the amount of available soil nitrogen and the less complete and slower control of diseases explain the reduction in potato tuber yield under low-input systems. Maggio et al. [3] found 25\% reduction in potato marketable yield under the organic system compared to the conventional system with higher percentage of large tubers under the conventional system. Zarzyńska and Pietraszko [155] compared the tuber yield of four potato cultivars (Viviana, Gawin, Legenda, Gustaw) grown under organic and conventional management practices and found that the organic system resulted in less than optimal plant growth, tuber yield, and tuber size, with the greatest number of small tubers under organic practices. From a six-year investigation of the effects of organic vs. conventional crop management practices (fertilization, crop protection) and preceding crop on potato tuber yield and quality, Palmer at al. [144] found that total and marketable yields were significantly reduced by the use of both organic crop protection and fertility management. Moreover, the yield gap between organic and conventional fertilization regimes was greater and more variable due to lower or less predictable nitrogen supply in organic fertilizer practice than that between crop protection practices [144]. Ierna and Parisi [156] reported that organic cultivation system was less productive (5 to $50 \%$ less) than the conventional due to less availability of nitrogen and to appearance time and severity level of late blight infection. However, Fiorillo et al. [157] and Warman and Havard [4] found no tuber yield reduction under organic farming. Warman [158] suggested that variation in weather has a greater influence on productivity than the kind of fertilizer adopted.

Table 2. Comparative analysis of characteristics differences between organically and conventionally grown potatoes.

\begin{tabular}{clc}
\hline References & \multicolumn{1}{c}{ Major Research Findings } & \multicolumn{1}{c}{ Locations } \\
\hline \multirow{2}{*}{ Warman and Havard [4] } & The yield and vitamin C content of the potatoes was not affected by treatments. \\
\cline { 2 - 3 } & $\begin{array}{l}\mathrm{P}, \mathrm{Mg}, \mathrm{Na} \text { and Mn content in potato tubers and } \mathrm{N}, \mathrm{Mg}, \text { Fe and B content in leaves were } \\
\text { influenced by treatments. }\end{array}$ \\
\hline
\end{tabular}

Potatoes from organic systems had $18 \%$ more total phenolics than those from conventional systems.

The nitrate content in organically grown tubers was 34\% lower than conventional

Lombardo et al. [13] products.

Italy

Ascorbic acid content of conventionally produced tubers were $23 \%$ greater than from organic systems.

Better sensory performance after frying (crispness and less browning) was observed in potatoes from organic than conventional systems.

Conventional farming yield is significantly higher than that obtained by organic.

The farming type has no significant effect on the content of phenolic acids.

No significant effect of farming type on dry matter and starch content, or sensory properties was found. 
Table 2. Cont.

\begin{tabular}{ll}
\hline \multicolumn{1}{c}{ References } & \multicolumn{1}{c}{ Major Research Findings } \\
\hline \multirow{2}{*}{ Lombardo et al. [159] } & \begin{tabular}{l} 
The organic cultivation system was less productive than the conventional. \\
\cline { 2 - 3 } \\
The organic farming produced tubers with a lower nitrate content, an important \\
benefit in the context of human health.
\end{tabular} \\
\hline Soltoft et al. [160] & $\begin{array}{l}\text { Higher concentration of the phenolic 5-caffeoylquinic acid was detected in potatoes } \\
\text { produced organically. }\end{array}$
\end{tabular}

The largest starch content in the peel and the bulk of the tubers was observed in the conventional system ( $33.0 \%$ and $78.1 \%$, respectively).

The lowest contents of starch content in the peel and the bulk of the tubers were

Dramićanin et al. [161] identified in the organic cropping system (22.7\% and $65.2 \%$, respectively).

The highest content of fructose, glucose, and saccharose in tubers was identified in the conventional system, followed by integral, and being the lowest in the organic cultivation system.

Zarzyńska and Pietraszko The organic production system resulted in less than optimal plant growth, tuber yield [155] and tuber size.

Organic farming caused a $25 \%$ marketable yield reduction with a higher percentage of large tubers under conventional farming.

Maggio et al. [3]

Highest starch values were found in organic Merit and conventional Agria cultivars.

The total protein content was higher in both Agria and organically grown tubers and it also corresponded to higher total amino acid contents. Specifically, organic farming increased only threonine, whereas it significantly reduced most of the other amino acids.

Incorporation of mustard residues (B. juncea) consistently resulted in greater effects on

Larkin et al. [113] soil microbial communities and greater reductions in soilborne diseases than additions of other organic amendments.

Higher contents of polyphenols (sum), phenolic acids (sum), chlorogenic acid, p-coumaric acid, and cafeic acid were found in biodynamic and organic samples compared to the conventional tubers.

Organically and biodynamically produced potatoes were significantly richer in Vaitkeviciene et al. [162] flavonoids and anthocyanins.

Content of polyphenols (sum), phenolic acids (sum), chlorogenic acid, p-coumaric acid, caffeic acid, carotenoids (sum), lutein, and $\beta$-carotene showed no significant difference among the conventional and organic samples.

Organically and biodynamically cultivated potatoes (except the "Salad Blue" cultivar) were essentially richer in flavonoids and anthocyanins.

Larkin et al. [56] Disease-suppressive green manures and cover crops, produced the highest yields overall under irrigation.

The organic cultivation system produced tubers of higher nutritional value, specifically exhibiting a higher total phenolic content (5.76 vs. $4.28 \mathrm{~g} \mathrm{~kg}^{-1}$ dry matter,

Lombardo et al. [14] averaged across locations and cultivars) and a lower nitrate content (0.64 vs. $1.04 \mathrm{~g}$ $\mathrm{kg}^{-1}$ dry matter, averaged across locations and cultivars), and displaying a more attractive color of both the skin and flesh.

Organic farming was characterized by higher antioxidant capacity.

There was better development of antioxidant properties of potato tubers in the organic cultivation system when compared with the integrated system.

Potato tubers grown under two different production systems irrespective of location and variety or clone showed significant differences in the content of total phenolics, total flavonoids, ascorbic acid and citric acid. 
Table 2. Cont.

\begin{tabular}{lll}
\hline \multicolumn{1}{c}{ References } & \multicolumn{1}{c}{ Major Research Findings } & \multicolumn{1}{c}{ Locations } \\
\hline \multirow{3}{*}{ Palmer et al. [144] } & $\begin{array}{l}\text { Total and marketable yields were significantly reduced by the use of both organic crop } \\
\text { protection and fertility management. }\end{array}$ & England \\
\cline { 2 - 3 } & $\begin{array}{l}\text { Yield gap between organic and conventional fertilization regimes was greater and } \\
\text { more variable than that between crop protection practices. }\end{array}$ \\
\hline Bartova et al. [164] & Organic potatoes contained significantly less nitrogen, nitrates and $\alpha$-solanin. & $\begin{array}{l}\text { Protein content, patatin relative abundance in total tuber protein and patatin content } \\
\text { in organically produced tubers were on the lower end of the range than conventional } \\
\text { tubers but the differences were not statistically significant. }\end{array}$ \\
\hline
\end{tabular}

Compost amendment had variable effects on tuber diseases, but consistently increased yield (by 9 to $15 \%$ ).

Bernard et al. [106] Rapeseed rotation reduced all observed soilborne diseases (stem canker, black scurf, common scab, and silver scurf) by 10 to $52 \%$.

Combining rapeseed rotation with compost amendment both reduced disease and increased yield.

Mean content of crude protein was significantly higher in tubers from organic crop management than in tubers from conventional system (10.9 and 9.7\% in dry matter, respectively).

Diviš et al. [165] Cultivar was the factor having the highest direct effect on crude protein as well as protein contents.

Tubers from conventional crop management showed an increased tendency to accumulate nitrates.

$\mathrm{N}$ availability was most important in limiting yields in organic potato crops.

Only $25 \%$ of this variation in yield could be attributed to the influence of late blight.

Moeller and Reents [166]

In organic farming, yields are mainly limited by nutrient availability in spring and early summer.

The higher the $\mathrm{N}$ status of a potato crop, the longer the growing period needed to achieve the attainable yield and the higher the probability that late blight stops further tuber growth and becomes the key tuber-yield-limiting factor.

Potato cultivars Aladin and Almera are suitable varieties for growers of Lazio region who may be interested to switch from conventional to organic management system due to the highest marketable yield especially of medium-size tubers (45-75 $\mathrm{mm}$ ) and the low incidence of disease problems (common scab).

Fiorillo et al. [157]

Incidence of wireworm attacks (percentage) was almost 9 times higher in organic system in comparison to conventional system, leading to a reduction of marketable yield of medium tuber size.

The conventional potatoes had a lower dry matter content and a slightly softer texture than the organic potatoes.

Gilsenan et al. [22] No significant differences were noted between the organic and conventional baked potato samples for the sensory attributes of appearance, aroma, texture and taste acceptability.

\section{Tuber Specific Gravity and Dry Matter Content}

Potato tuber specific gravity is an important characteristic for processing potato quality, and it represents the dry matter content of tubers. Potato tubers with high specific gravity show higher dry matter content and produce potato chips or fries with light color with less oil absorption [167]. Dale et al. [168] and Haase [169] indicated that the dry matter content of potato tuber linked with specific gravity is a main determinant of potato quality. Potato dry matter content has been grouped as high dry matter content ( $\geq 20 \%$ ), intermediate (between 18 and $19.9 \%$ ), and low ( $\leq 17.9 \%)$ [170]. A dry matter 
content $\geq 20 \%$ and a specific gravity $\geq 1.08$ are standard references of the processing industries [169,171]. Lombardo et al. [152] and Herencia et al. [172] reported higher dry matter content in organically fertilized potatoes, and other studies have also shown higher dry matter content in organically grown potatoes compared to conventional production systems $[5,13,154,173]$. However, Woese et al. [6] found no difference in potato dry matter content between the organically and conventionally grown potatoes.

\section{Sugar and Starch Contents of Potato Tubers}

Glucose and fructose are prevalent reducing monosaccharides with concentrations between $0.15 \%$ and $1.5 \%$ in potato tubers [161] while the disaccharide saccharose is the most abundant sugar component in potatoes at a content between 0.4 to $6.6 \%$, and other sugars are present in traces [174-176]. Starch is another large component of potato tubers (60-80\% of potato dry matter), which defines the inner and / or outer quality of the potato product [177]. Arvanitoyannis et al. [178] reported that the ratio of the starch content to the reducing sugars content is a quality index that determines the suitability of potato for industrial processing. Starch and reducing sugar content in potato tubers are considered as a primary nutritional quality indicator for consumers, particularly those under increasing diabetes threat. However, the non-reducing sugars are converted into reducing sugars, and lead to the formation of acrylamide through a Maillard reaction with asparagines [179]. Therefore, high content of glucose and fructose as reducing sugars in potato is an undesirable trait [142,180-184]. Reducing sugars accumulation in potato tubers occurs ordinarily only under organic systems [3]. From field experiments involving four varieties, three environments and three farming systems (conventional, integrated, and organic), Dramićanin et al. [161] found that starch content in the potato tubers may be considered an important indicator of the type of production, botanical origin, and ripening time and the sugar macro- and microcomponents such as fructose, glucose, saccharose, sorbitol, trehalose, arabinose, turanose, and maltose were the main factors for the differentiation of production types, production years, and botanical origin of potato. An increase in total sugars was noted for organic potatoes when compared to conventional potatoes [185-187]. In contrast, Leonel et al. [16] reported that potato tubers fertilized with increased $\mathrm{P}$ exhibited a lower concentration of total sugar contents. Wadas and Dziugiet [188] found that the use of plant biostimulant (the seaweed extracts Bio algeen S90 (Ascophyllum nodosum) and Kelpak SL (Ecklonia maxima), as well as humic and fulvic acids) had a significant effect on starch content in potato cultivars Denar, Lord, and Miłek tubers but did not affect the content of total sugars (glucose, fructose, and sucrose), monosaccharides (glucose and fructose), or sucrose. In contrast, Grze'skiewic et al. [189] reported that the starch content of the potato tubers of the medium-early cultivar Muza was not affected by application of the Bio-algeen S90. Starch content in potato tubers of early cultivars Arizona and Riviera and medium-early cultivars Agria had increased under biostimulants based on A. nodosum extracts (Phylgreenmira, Algazone, Ultra-Kelp) [190]. The humic substance molecular size, molecular characteristics, and concentration affect the non-enzymatic activities, showing contradictory results for starch content in potato tubers [191-196].

Lombardo et al. [14] and Dramićanin et al. [161] reported that the most abundant sugars in both the bulk and the peel potato were fructose, glucose, and saccharose while sorbitol, trehalose, arabinose, turanose, galactitol, galactose, xylose, melibiose, maltose, gentiobiose, isomaltose, iso-maltotriose, ribose, panose and maltotriose, were found in traces [175]. Dramićanin et al. [161] found significant effect of production type on the sugar content of potato tubers; the largest starch content in the peel $(33.0 \%)$ and the bulk (78.1) of the tubers was observed in the conventional system, followed by the integral system with $28.2 \%$ and $67.5 \%$ in the peel and the bulk, respectively. The peel and the bulk potato grown under organic system had the lowest contents of starch with $22.7 \%$ and $65.2 \%$, respectively. Tein et al. [197] indicated that crop growth and development under conventional system are improved by extensive application of pesticides and fertilizers 
while under the organic system, the use of synthetic fertilizer and pesticides are not allowed. Lombardo et al. [14] reported that the low starch content of potato tubers grown under organic systems is due to the auto-consumption of part of the starch by the plant for its growth and development since no fertilizers are applied [161]. Dramićanin et al. [161] found that potato tuber contents in glucose, fructose, sucrose, sorbitol, trehalose, arabinose, turanose, maltose, and other simple sugars vary with the production systems with the highest content of the glucose, fructose, and sucrose in the conventional system, followed by integral and organic production systems. The starch and the sugar in potato tubers may be used as a promising tool in tracing the differences between potato cultivation systems, botanical origin, and ripening time [161].

\section{Nitrate Content of Potato Tubers}

Organically grown potatoes generally contain less nitrate [198-201] than conventionally grown potatoes (Table 2). Lombardo et al. [13] found that the nitrate content in organically grown tubers was $34 \%$ less than in conventionally grown potatoes. Similarly, studies have shown lower amounts of dry matter [5,80], vitamin C [186], total amino acids [3], and total protein in organic potatoes [3,202]. Bartova et al. [164] also reported that organically produced tubers contained a significantly lower content of total nitrogen and crude protein compared to the conventionally grown potato. Kazimierczak et al. [154] found lower concentrations of nitrates and lutein in organic tubers of cultivars Mazur, Justa, Lawenda, Lech, Tacja, Laskana, Otolia, and Magnolia. The non-availability of nitrogen under organic farming is compensated by the higher soil residual nitrogen content, which increases the concentration of nitrates in plants [203]. Bártová et al. [164] reported that organic potatoes contained significantly lower nitrogen, nitrates, and $\alpha$-solanin contents compared to the conventionally grown potatoes while the protein and patatin contents were not significantly different between production systems.

In contrast, Divís et al. [165] reported that mean contents of crude protein and in protein content in dry matter were significantly higher in organically grown potato tubers than in tubers from conventional practice. They found that potato genotype or cultivar was the factor with the highest direct effect on crude protein and protein contents in the potato tubers. Makaraviciute [204] and Maggio et al. [3] reported non-significant differences in potato content in essential amino acids between organic and conventional potato tubers. Shepherd et al. [205] found that mass-spectrometry and gas chromatography analysis of polar compounds identified 83 metabolites showing significant differences in the metabolome between the organic and conventional farming with 62 metabolites (dominated by free amino acids) being less abundant in tuber samples from organic compared with conventionally grown plots due to the $50 \%$ lower nitrogen content of the organically grown potatoes than for conventional production. Lombardo et al. [13] found that total protein amount was independent of the farming management system. However, on the basis of peptide composition, protein quality as nutritional value is superior in the organically grown potato tubers than the conventionally grown potato tubers [187].

\section{Bioactive Compounds and Antioxidants Content in Potato Tubers}

The polyphenol content of potato increases under stress conditions as a protection response from the potato plant by producing large numbers of specialized compounds of secondary metabolism $[153,160,206-209]$. Potato tubers contain important levels of bioactive compounds and antioxidants, including phenolic acids mainly chlorogenic acid with concentrations that vary from 49 to $1400 \mathrm{mg} / \mathrm{kg}$ dry matter [210,211], ascorbic acid [14,152,212], and flavonoids from 200 to $300 \mathrm{mg} / \mathrm{kg}$ of fresh mass, which are phytochemicals known to reduce the risk of several human diseases such as cardiovascular disease, high cholesterol, and cancer [14,152,210,212-219]. Indeed, polyphenols and other plant-derived antioxidants are widely known to prevent various types of cancers, cardiovascular diseases, and other diseases. For example, potato anthocyanins and phenolic acids suppress the proliferation of human melanoma and glioblastoma cells [216,220]. Nichenametla et al. [221] indicated that 
chlorogenic and ferulic acid decreased lung tumors in rats by $30-40 \%$. The anthocyanins and their aglycones present in red- and purple-fleshed potatoes have been found to exert proapoptotic and antiproliferative properties in gastric adenocarcinoma, colon cancer, and bovine aortic endothelial cells $[222,223]$. Under limited nitrogen availability similar to organic farming systems, plant growth is limited, and plant's metabolism shifts towards C-rich compounds such as starch and phenolic compounds [187]. Vaitkevičienė et al. [162] found higher contents of polyphenols, phenolic acids, chlorogenic acid, p-coumaric acid, cafeic acid, flavonoids, and anthocyanins in potato tubers grown organically or biodynamically than in the conventionally grown potato cultivars Red Emmalie, Salad Blue, Violetta, Tornado, and Laura. Similar findings were reported by Kazimierczak et al. [154], Jeon et al. [224], Hamouz et al. [225], and Baranski et al. [201]. However, phenolic content in the potato tubers depends on the genotypes, climatic conditions, and conditions during storage period after harvest $[153,226-228]$. Potato cultivar Violetta, with a dark purple flesh, accumulated the highest contents of flavonoids, anthocyanins, petunidin-3,5-di-Oglucoside, pelargonidin-3,5-di-O-glucoside, and peonidin-3,5-di-O-glucoside. Colored potatoes are known for their unique sensory appeal, nutritional value, and antioxidant activities as they are rich in polyphenols, anthocyanins, flavonoids, carotenoids, tocopherols, and vitamin C [162,229]. Tatarowska et al. [230] found that carotenoid content in potato tubers was higher under organic production compared to the conventional production. Kazimierczak et al. [154] reported significantly higher contents of flavonoids, quercetin, and quercetin-3-O-rutinoside in organically grown potato tubers compared to the conventionally grown tubers. Conversely, Brazinskiene et al. [153] found that the farming system had no significant effect on phenolic acid concentrations in the potato tubers while Keutgen et al. [163] found higher contents of phenolic compounds, flavonoids, and ascorbic acid in organically grown potato tubers than the conventionally grown potato tubers. Romero-Pérez et al. [231] found that flavonoids in plants are strongly impacted by genotype, the agroclimatic conditions, and the cultivation system. Interestingly, Lachman et al. [232] and Vaitkevičiene et al. [162] derived from their study that the colored-flesh potato genotypes have a greater impact on the anthocyanins content than the agricultural production system and they are not detected in white- or yellow-flesh potato tubers [162,233,234].

On the one hand, Ezekiel et al. [235] found no differences in phenolic contents in tubers grown in organic and integrated farming systems. However, Grudzińska et al. [217] and Lombardo et al. [14] found higher total phenolics content in potato tubers under organic production. Lombardo et al. [14] indicated that the higher concentration of phenolic compounds in the organically grown potato tubers was the result of diseases and pest pressure and lower nitrogen availability under organic farming. Phenolic compounds accumulations might be genotype dependent. Keutgen et al. [163] reported that the highest amounts of phenolic compounds were found in potato cultivar Satina $(3.48 \pm 0.57 \mathrm{~g} / \mathrm{kg}$ of dry matter) as a genetic ability of that cultivar to accumulate phenolics. Similar findings were reported by Gugala et al. [236], and similar development ability of flavonoids was reported by Keutgen et al. [163]. Smith-Spangler et al. [212] and Grudzińska et al. [217] reported higher ascorbic acid content in the organically grown potato tuber while Keutgen et al. [163] found the opposite trend in their study and indicated that the discrepancy might be due to the limited availability of nitrogen in the organic production systems and the reduced above-ground biomass, for the buildup of which photosynthates could have been used. Some studies reported that potato tuber content in ascorbic acid is cultivar dependent $[13,237,238]$.

\section{Mineral and Vitamin Contents}

Potato tuber content might be impacted by soil and plant management practices (Table 2). Wszelaki et al. [185] found that potassium, magnesium, phosphorus, sulfur, and copper concentrations in tuber skin and flesh were also significantly higher in the organic treatments, while iron and manganese concentrations were higher in the skin of conventionally grown potatoes. Lombardo et al. [159] investigated early potato tuber 
mineral contents under organic and conventional farming and found that the potato tubers contained more phosphorus ( 2.8 vs. $2.3 \mathrm{~g} \mathrm{~kg}^{-1}$ of dry matter) and a comparable quantity of both magnesium and copper (on average 250 and $2.6 \mathrm{mg} \mathrm{kg}^{-1}$ of dry matter, respectively) under organic farming than the conventional farming. Wszelaki et al. [185] found tuber skin and flesh to have significantly higher concentration in potassium, magnesium, phosphorus, sulfur, and copper under organic management than conventional practices, while iron and manganese contents were higher in the skin of conventionally grown potatoes.

Contradictory data have also been reported between the organically grown and conventionally grown potato with respect to vitamin C content $[4,239,240]$. Warman and Havard [4] found that there was no significant difference in vitamin C content of the potato tubers grown under organic and conventional practices. Conversely, other studies have reported higher vitamin $\mathrm{C}$ content in the organic potato tubers than in the conventional potato tubers $[80,186,241]$.

\section{Sensory Characteristics of Potato Tubers}

Crop management practices have not shown any significant effect on sensory properties of early potato cultivar tubers boiled [242], unpeeled tubers boiled in steam [186], or raw samples of potato [243]. However, potato cultivar and production year are important influences on sensory quality of boiled potatoes [186]. Potato skin might have significant property as consumers usually differentiate samples with skin from different cultivars as compared to samples without skin [185,244,245]. Lombardo et al. [13] found that potato cultivars Ditta and Nicola were well suited to boiling with a delicate taste, firmness, and absence of blackening. Moreover, potato cultivars Arinda, Ditta, and Nicola grown organically had a better sensory performance after frying (strong taste and crisp flesh) than the conventionally grown potato. There was no significant difference in farming systems with regards to consistency, typical taste after boiling [13,186,245], or typical taste after frying; however, organically grown potato tuber showed higher crispiness and lower browning index [13]. Woese et al. [6] found no clear and consistent statements about the high sensorial quality of organic potatoes vs. conventional potatoes from different studies on the organoleptic quality in organic practices compared to the conventional practices.

Potato threshold concentration in solanine of $140 \mu \mathrm{g} \mathrm{g}^{-1}$ causes bitter taste, and solanine concentration greater than $200 \mu \mathrm{g} \mathrm{g}^{-1}$ creates a burning sensation in the throat and on the tongue [246]. Gilsenan et al. [22] found that the conventional potatoes had a lower dry matter content and a slightly softer texture than the organic potatoes. The conventional baked potato was also slightly softer, less adhesive, and wetter than the organic baked potato, but there was no significant difference between the organic and conventional baked potato samples for the sensory attributes of appearance, aroma, texture, and taste acceptability [22]. Brazinskiene et al. [153] reported that odor and taste intensity of the potato samples were not affected by farming practices.

\section{Conclusions}

This review has explored the characteristics of organically grown potato tubers compared to the conventionally grown potatoes. Across several studies comparing potato farming practices, it can be derived that potato total tuber and marketable yield is lower under organic farming than under conventional farming. Weed and disease pressure is more intense under the organic farming and the lower nitrogen available for potato plant infers low nitrogen content in the organically grown potato tuber. Organic potato tubers contain higher sugar content compared to the conventionally grown tubers. Organic potato tubers show high polyphenol compounds content due to the stress occurring under the organic practices (limited nutrients and increasing disease pressure) compared to the conventional practices. Some contradictory results are reported on the impact of cropping systems on potato tuber content in minerals, vitamin C, sensory properties, and the dependence of several characteristics on the genotypic material. For future studies, it is crucial to match the best agronomic production practices and plant genotypic material 
to maximize the fresh potato and processed product contents in bioactive compounds to match the health-promoting properties for more production sustainability. Consumers are showing increasing interest in organically grown potatoes due to their nutritional quality and health protection value. Due to the lower tuber yield under organic farming, for the profitability of the production system, organic products are necessarily more expensive, and some consumers might be willing to pay the price for health-promoting properties.

Author Contributions: Conceptualization, K.D. and K.K.; methodology, K.D., S.S., K.K. and S.A.; writing-original draft preparation, K.D.; writing—review and editing, K.D., S.S., S.E., K.K., A.S. and S.A. All authors have read and agreed to the published version of the manuscript.

Funding: This research received no external funding.

Institutional Review Board Statement: Not applicable.

Informed Consent Statement: Not applicable.

Data Availability Statement: Not applicable.

Conflicts of Interest: The authors declare no conflict of interest.

\section{References}

1. FAO Statistical Database 2021. Available online: http://www.fao.org/faostat/en/\#home (accessed on 19 March 2021).

2. Horton, D.E.; Anderson, J.L. Potato production in the context of the world and farm economy. In The Potato Crop; Harris, P.M., Ed.; Chapman and Hall: London, UK, 1992; pp. 804-805.

3. Maggio, A.; Carillo, P.; Bulmetti, G.S.; Fuggi, A.; Barbieri, G.; De Pascale, S. Potato yield and metabolic profiling under conventional and organic farming. Eur. J. Agron. 2008, 28, 343-350. [CrossRef]

4. Warman, P.R.; Havard, K.A. Yield, vitamin and mineral contents of organically and conventionally grown potatoes and sweet corn. Agric. Ecosyst. Environ. 1998, 68, 207-216. [CrossRef]

5. Moschella, A.; Camin, F.; Miselli, F.; Parisi, B.; Versini, G.; Ranalli, P. Markers of characterization of agricultural regime and geographical origin in potato. Agroindustria 2005, 4, 325-332.

6. Woese, K.; Lange, D.; Boess, C.; Bogl, K.W. A comparison of organically and conventionally grown foods-Results of a review of the relevant literature. J. Sci. Food Agric. 1997, 74, 281-293. [CrossRef]

7. Djaman, K.; Irmak, S.; Koudahe, K.; Allen, S. Irrigation management in potato (Solanum tuberosum L.) production: A review. Sustainability 2021, 13, 1504. [CrossRef]

8. Zarzynska, K.; Boguszewska-Mankowska, D.; Nosalewicz, A. Differences in size and architecture of the potato cultivars root system and their tolerance to drought stress. Plant. Soil Environ. 2017, 63, 159-164. [CrossRef]

9. Romero, A.P.; Alarcón, A.; Valbuena, R.I.; Galeano, C.H. Physiological assessment of water stress in potato using spectral information. Front. Plant Sci. 2017, 8, 1608. [CrossRef]

10. Gastal, F.; Lemaire, G. N uptake and distribution in crops: An agronomical and ecophysiological perspective. J. Exp. Bot. 2002, 53, 789-799. [CrossRef]

11. Wang, Z.H.; Zong, Z.Q.; Li, S.X.; Chen, B.M. Nitrate accumulation in vegetables and its residual in vegetable fields. Environ. Sci. 2002, 23, 79-83.

12. Van Delden, A.; Schroder, J.J.; Kropff, M.J.; Grashoff, C.; Booij, R. Simulated potato yield, and crop and soil nitrogen dynamics under different organic nitrogen management strategies in the Netherlands. Agric. Ecosyst. Environ. 2003, 96, 77-95. [CrossRef]

13. Lombardo, S.; Pandino, G.; Mauromicale, G. Nutritional and sensory characteristics of "early" potato cultivars under organic and conventional cultivation systems. Food Chem. 2012, 133, 1249-1254. [CrossRef]

14. Lombardo, S.; Pandino, G.; Mauromicale, G. The effect on tuber quality of anorganic versus a conventional cultivation system in theearly crop potato. J. Food Compos. Anal. 2017, 62, 189-196. [CrossRef]

15. Mauromicale, G.; Ierna, A. Patata primaticcia. In Fisiononomia e Profili di Qualità dell'Orticoltura Meridionale; Bianco, V.V., La Malfa, G., Tudisca, S., Eds.; Arti Grafiche Siciliane: Palermo, Italy, 1999; pp. 275-296.

16. Leonel, M.; do Carmo, E.L.; Fernandes, A.M.; Soratto, R.P.; Eburneo, J.A.M.; Garcia, E.L. Chemical composition of potato tubers: The effect of cultivars and growth conditions. J. Food Sci. Technol. 2017, 54, 2372-2378. [CrossRef]

17. Djaman, K.; Higgins, C.; Allen, S.; Komlan Koudahe, K.; Lombard, K. Tuber yield, water productivity and post-harvest quality of sprinkler-irrigated chip potato (Solanum tuberosum L.) under a semiarid climate. J Agric. Hortic. Res. 2019, 2, 1-9. [CrossRef]

18. Bacchi, M.A.; De Nadai Fernandes, E.A.; Tsai, S.M.; Santos, L.G.C. Conventional and organic potatoes: Assessment of elemental composition using k0-INAA. J. Radioanal. Nucl. Chem. 2004, 259, 421-424. [CrossRef]

19. Navarro Pedreno, J.; Moral, R.; Gomez, I.; Mataix, J. Reducing nitrogen losses by decreasing mineral fertilization in horticultural crops of eastern Spain. Agric. Ecosyst. Environ. 1996, 59, 217-221. [CrossRef]

20. Santamaria, P. Nitrate in vegetable: Toxicity, content, intake and EC regulation. J. Sci. Food Agric. 2006, 86, 10-17. [CrossRef] 
21. Hoefkens, C.; Vandekinderen, I.; De Meulenaer, B.; Devlieghere, F.; Baert, K.; Sioen, I.; De Henauw, S.; Verbeke, W.; Van Camp, J. A literature-based comparison of nutrient and contaminant contents between organic and conventional vegetables and potato. $\mathrm{Br}$. Food J. 2009, 111, 1078-1098. [CrossRef]

22. Gilsenan, C.; Burke, R.M.; Barry-Ryan, C. A study of the physicochemical and sensory properties of organic and conventional potatoes (Solanum tuberosum) before and after baking. Int. J. Food Sci. Technol. 2010, 45, 475-481. [CrossRef]

23. Aguilera, J. Fritura de alimentos. In Temas en Tecnologıa de Alimentos; Aguilera, J.M., Ed.; Alfaomega Grupo Editor: Santiago, Chile, 1997; Volume 1, pp. 187-211.

24. Moreira, R.; Castell-Perez, M.E.; Barrufet, M.A. Deep-Fat Frying: Fundamentals and Applications; Aspen Publishers: Gaithersburg, MD, USA, 1999; 350p.

25. Thygesen, L.G.; Thybo, A.K.; Engelsen, S.B. Prediction of sensory texture quality of boiled potatoes from low-field HNMR of raw potatoes. Lebensm. Wiss. Technol. 2001, 34, 469-477. [CrossRef]

26. Ross, K.A.; Scanlon, M.G. A fracture mechanics analysis of the texture of fried potato crust. J. Food Eng. 2004, 62, 417-423. [CrossRef]

27. Moyano, P.C.; Troncoso, E.; Pedreschi, F. Modeling texture kinetics during thermal processing of potato products. J. Food Sci. 2007, 72, 102-107. [CrossRef]

28. Rosen, J.; Hellenas, K.E. Analysis of acrylamide in cooked foods by liquid chromatography tandem mass spectrometry. Analyst 2002, 127, 880-882. [CrossRef] [PubMed]

29. Troncoso, E.; Pedreschi, F. Modeling of textural changes during drying of potato slices. J. Food Eng. 2007, 82, 577-584. [CrossRef]

30. Troncoso, E.; Pedreschi, F. Modeling water loss and oil uptake during vacuum frying of pre-treated potato slices. LWT Food Sci. Technol. 2009, 42, 1164-1173. [CrossRef]

31. Watada, A.E.; Kunkel, R. The variation in reducing sugar content in different varieties of potatoes. Am. Potato J. 1955, 32, 132-140. [CrossRef]

32. Habib, A.T.; Brown, H.D. Role of reducing sugars and amino acids in the browning of potato chips. Food Technol. 1957, 11, 85-89.

33. Smith, O. Factors affecting and methods of determining potato chip quality. Am. Potato J. 1961, 38, 265-271. [CrossRef]

34. Danehy, J.P. Maillard reactions: Nonenzymatic browning in food systems with special reference to the development of flavor. Adv. Food Res. 1986, 30, 77-138.

35. Serpen, A.; Gökmen, V. Evaluation of the Maillard reaction in potato crisps by acrylamide, antioxidant capacity and color. J. Food Compos. Anal. 2009, 22, 589-595. [CrossRef]

36. Scanlon, M.G.; Roller, R.; Mazza, G.; Pritchard, M.K. Computerized video image analysis to quantify color of potato chips. Am. Potato J. 1994, 71, 717-733. [CrossRef]

37. Marquez, G.; Anon, M.C. Influence of reducing sugars and amino acids in the color development of fried potatoes. J. Food Sci. 1986, 51, 157-160. [CrossRef]

38. Pszczółkowski, P.; Sawicka, B. Attempts to reduce weed infestation of potato in cultivation under cover. Part II. Weight, abundance and species composition of weeds. Biul. IHAR 2003, 228, 261-273.

39. Baranowska, A.; Mystkowska, I.; Zarzecka, K.; Gugała, M. Efficacy of herbicides in potato crop. J. Ecol. Eng. 2016, 17, 82-88. [CrossRef]

40. Barbaś, P.; Sawicka, B.; Marczak, B.K.; Pszczółkowski, P. Effect of mechanical and herbicide treatments on weed densities and biomass in two potato cultivars. Agriculture 2020, 10, 455. [CrossRef]

41. Boydston, R.A. Managing weeds in potato rotations without herbicides. Am. J. Pot Res. 2010, 87, 420-427. [CrossRef]

42. Boydston, R.A.; Hang, A. Rapeseed (Brassica napus) green manure crop suppresses weeds in potato (Solanum tuberosum). Weed Technol. 1995, 9, 669-675. [CrossRef]

43. Mojtahedi, H.; Santo, G.S.; Ingram, R.E. Suppression of Meloidogyne chitwoodi with sudangrass cultivars as green manure. J. Nematol. 1993, 25, 303-311. [PubMed]

44. Mojtahedi, H.; Santo, G.S.; Wilson, J.H.; Hang, A.N. Managing Meloidogyne chitwoodi on potato with rapeseed as green manure. Plant. Dis. 1993, 77, 42-46. [CrossRef]

45. Putnam, A.R.; DeFrank, J. Use of phytotoxic plant residues for selective weed control. Crop. Prot. 1983, 2, 173-181. [CrossRef]

46. Weston, L.A.; Harmon, R.; Mueller, S. Allelopathic potential of sorghum-sudangrass hybrid (Sudex). J. Chem. Ecol. 1989, 15, 1855-1865. [CrossRef] [PubMed]

47. Lanfranconi, L.E.; Bellinder, R.R.; Wallace, R.W. Grain rye residues and weed control strategies in reduced tillage potatoes. Weed Technol. 1993, 7, 23-28. [CrossRef]

48. Creamer, N.G.; Bennett, M.A.; Stinner, B.R.; Cardina, J.; Regnier, E.E. Mechanisms of weed suppression in cover crop-based production systems. Hort. Sci. 1996, 31, 410-413. [CrossRef]

49. Boydston, R.; Vaughn, S.F. Alternative weed management systems control weeds in potato (Solanum tuberosum). Weed Technol. 2002, 16, 23-28. [CrossRef]

50. Larkin, R.P.; Griffin, T.S. Control of soilborne diseases of potato using Brassica green manures. Crop Prot. 2007, 26, 1067-1077. [CrossRef]

51. Clark, A. Managing Cover Crops Profitably, 3rd ed.; Sustainable Agriculture Network: Beltsville, MD, USA, 2007.

52. Ngouajio, M.; Mannan, H. Weed populations and pickling cucumber (Cucumis sativus) yield under summer and winter cover crop systems. Crop. Prot. 2005, 24, 521-526. [CrossRef] 
53. Everts, K.L.; Sardanelli, S.; Kratochvil, R.J.; Armentrout, D.K.; Gallagher, L.E. Rootknot and root-lesion nematode suppression by cover crops, poultry litter and poultry litter compost. Plant. Dis. 2006, 90, 487-492. [CrossRef]

54. Larkin, R.P.; Halloran, J.M. Management effects of disease suppressive rotation crops on potato yields and soilborne diseases and their economic implications in potato production. Am. J. Potato Res. 2014, 91, 429-439. [CrossRef]

55. Nyiraneza, J.; Peters, R.D.; Rodd, V.A.; Grimmett, M.G.; Jiang, Y. Improving productivity of managed potato cropping systems in Eastern Canada: Crop rotation and nitrogen source effects. Agron. J. 2015, 107, 1447-1457. [CrossRef]

56. Larkin, R.P.; Honeycutt, C.W.; Griffin, T.S.; Olanya, O.M.; He, Z. Potato growth and yield characteristics under different cropping system management strategies in Northeastern, U.S. Agronomy 2021, 11, 165. [CrossRef]

57. Brown, P.D.; Morra, M.J. Control of soil-borne plant pests using glucosinolate-containing plants. Adv. Agron. 1997, 61, 167-231.

58. Melrose, J. The Glucosinolates: A sulphur glucoside family of mustard anti-tumour and antimicrobial phytochemicals of potential therapeutic application. Biomedicines 2019, 7, 62. [CrossRef]

59. Rubel, M.H.; Abuyusuf, M.; Nath, U.K.; Robin, A.H.K.; Jung, H.J.; Kim, H.T.; Park, J.I.; Nou, I.S. Glucosinolate profile and glucosinolate biosynthesis and breakdown gene expression manifested by black rot disease infection in cabbage. Plants 2020, 9 , 1121. [CrossRef] [PubMed]

60. Hartsema, O.H.; Molendijk, K.P.; van der Berg, L.P.G.; Plentinger, M.C.; Hoek, J. Rotational Research Paratrichodorus teres (19912000); Practical Research Plant and Environment: Utrecht, The Netherlands, 2005; p. 85.

61. Campiglia, E.; Paolini, R.; Colla, G.; Mancinelli, R. The effects of cover cropping on yield and weed control of potato in a transitional system. Field Crops Res. 2009, 112, 16-23. [CrossRef]

62. Griffin, T.S.; Larkin, R.P.; Honeycutt, C.W. Delayed tillage and cover crop effects in potato systems. Am. J. Potato Res. 2009, 86, 79-87. [CrossRef]

63. Eberlein, C.V.; Patterson, P.E.; Guttieri, M.J.; Stark, J.C. Efficacy and economics of cultivation for weed control in potato (Solanum tuberosum). Weed Technol. 1997, 11, 257-264. [CrossRef]

64. Felix, J.; Ivany, J.; Kegode, G.O.; Doohan, D. Timing potato cultivation using the weed cast model. Weed Sci. 2009, 57, 87-93. [CrossRef]

65. VanderZaag, P. Toward sustainable potato production: Experience with alternative methods of pest and disease control on a commercial potato farm. Am. J. Pot. Res. 2010, 87, 428-433. [CrossRef]

66. Pawlonka, Z. Potato yield in monoculture under differentiated intensity of weed control. Prog. Plant. Prot. Postepy Ochr. Roslin 2007, 47, 229-233.

67. Lavlesh Raghav, M.; Sati, U.C.; Sati, K. Evaluating the manual and chemical methods for weed control inpotato (Solanum tuberosum L.) under Tarai conditions of Uttarakhand. Int. Q. J. Life Sci. 2017, 12, 683-686.

68. Zarzecka, K.; Gugała, M.; Grzywacz, K.; Sikorska, A. Agricultural and economic effects of the use of biostimulants and herbicides in cultivation of the table potato cultivar Gawin. Acta Sci. Pol. Agric. 2020, 19, 3-10. [CrossRef]

69. Finckh, M.R.; Schulte-Geldermann, E.; Bruns, C. Challenges to organic potato farming: Disease and nutrient management. Potato Res. 2006, 49, 27-42. [CrossRef]

70. El-Sayed, S.F.; Hassan, H.A.; El-Mogy, M.M. Impact of bio- and organic fertilizers on potato yield, quality and tuber weight loss after harvest. Potato Res. 2015, 58, 67-81. [CrossRef]

71. Hammad, A.M.M.; Abdel-Ati, Y.Y. Reducing of nitrate content of potato tuber via biofertilization with Azospirillum and via mycorrhizal fungi. J. Agric. Sci. Mansoura Univ. 1998, 23, 2597-2610.

72. Abou-Hussein, S.D.; El-Oksh, I.I.; El-Shorbagy, T.; El-Behairy, U.A. Effect of chicken manure, compost and biofertilizers on vegetative growth, tuber characteristics and yield of potato crop. Egypt J. Hortic. 2002, 29, 135-149.

73. Douds, D.D.; Nagahashi, G.; Reider, C.; Hepperly, P.R. Inoculation with arbuscular mycorrhizal fungi increases the yield of potatoes in a high P soil. Biol. Agric. Hortic. 2007, 25, 67-78. [CrossRef]

74. Bharadwaj, D.P.; Lundquist, P.-O.; Alström, S. Arbuscular mycorrhizalfungal spore-associated bacteria affect mycorrhizal colonization, plant growth and potato pathogens. Soil Biol. Biochem. 2008, 40, 2494-2501. [CrossRef]

75. Lone, R.; Shuab, R.; Sharma, V.; Kumar, V.; Mir, R.; Koul, K.K. Effect of arbuscular mycorrhizal fungi on growth and development of potato (Solanum tuberosum) plant. Asian J. Crop Sci. 2015, 7, 233-243. [CrossRef]

76. Hijri, M. Analysis of a large dataset of mycorrhiza inoculation field trials on potato shows highly significant increases in yield. Mycorrhiza 2016, 26, 209-214. [CrossRef]

77. Chifetete, V.W.; Dames, J.F. Mycorrhizal interventions for sustainable potato production in Africa. Front. Sustain. Food Syst. 2020, 4. [CrossRef]

78. Khosravifar, S.; Farahvash, F.; Aliasgharzad, N.; Yarnia, M.; Khoei, F.R. Effects of different irrigation regimes and two arbuscular mycorrhizal fungi on some physiological characteristics and yield of potato under field conditions. J. Plant Nutr. 2020, 43, 2067-2079. [CrossRef]

79. Carter, M.R.; Sanderson, J.B.; MacLeod, J.A. Influence of compost on the physical properties and organic matter fractions of a fine sandy loam throughout the cycle of a potato rotation. Can. J. Soil Sci. 2003, 4, 211-218. [CrossRef]

80. Rembialkowska, E. Comparison of the contents of nitrates, nitrites, lead, cadmium and vitamin $\mathrm{C}$ in potatoes from conventional and ecological farms. Pol. J. Food Nutrit. Sci. 1999, 8, 17-26.

81. Venkateswarlu, B.; Balloli, S.S.; Ramakrishna, Y.S. Organic Farming in Rainfed Agriculture; Central Research Institute for Dry Land Agriculture: Hyderabad, India, 2007; p. 88. 
82. Bin Zakaria, A.A. Growth optimization of Potassium Solubilizing Bacteria Isolated from Biofertilizer. Bachelor's Thesis, University Malaysia Pahang, Pahang, Malaysia, 2009; pp. 1-14.

83. Kamil, P.; Yami, K.D.; Singh, A. Plant growth promotional effect of Azotobacter chroococcum, Piriformospora indica and vermicompost on rice plant. Nepal J. Sci. Technol. 2008, 9, 85-90.

84. Jen-Hshuan, $\mathrm{C}$. The combined use of chemical and organic fertilizers and/or biofertilizer for crop growth and soil fertility. In Proceedings of the International Workshop on Sustained Management of the Soil-Rhizosphere System for Efficient Crop Production and Fertilizer Use, Bangkok, Thailand, 16-20 October 2006; pp. 1-10.

85. Rees, H.W.; Chow, T.L.; Zebarth, B.J.; Xing, Z.; Toner, P.; Lavoie, J.; Daigle, J.L. Effects of supplemental poultry manure applications on soil erosion and runoff water quality from a loam soil under potato production in northwestern New Brunswick. Can. J. Soil Sci. 2011, 91, 595-613. [CrossRef]

86. Bationo, A.; Nandwa, S.M.; Kimetu, J.M.; Kinyangi, J.M.; Bado, B.V.; Lompo, F.; Kimani, S.; Kihanda, F.; Koala, S. Sustainable intensification of crop-livestock systems through manure management in eastern and western Africa: Lessons learned and emerging research opportunities. In Sustainable Crop-Livestock Production for Improved Livelihoods and Natural Resource Management in West Africa, Proceedings of the International Conference. IITA Ibadan, Nigeria, 19-22 November 2001; Williams, T.O., Tarawali, S.A., Hiernaux, P., Fernandez, R.S., Eds.; ILRI: Nairobi, Kenya, 2004; 528p.

87. Lynch, D.H.; Zheng, Z.; Zebarth, B.J.; Martin, R.C. Organic amendment effects on tuber yield, plant N uptake and soil mineral N under organic potato production. Renew. Agric. Food Syst. 2008, 23, 250-259. [CrossRef]

88. Fahmy, S.H.; Sharifi, M.; Hann, S.W.; Chow, T.L. Crop productivity and nutrient bioavailability in a potato-based three-year rotation as affected by composted pulp fiber residue application and supplemental irrigation. Commun. Soil Sci. Plant. Anal. 2010, 41, 744-756. [CrossRef]

89. Canali, S.; Ciaccia, C.; Tittarelli, F. Soil fertility management in organic potato: The role of green manure and amendment applications. In Sustainable Potato Production: Global Case Studies; He, Z., Larkin, R., Honeycutt, W., Eds.; Springer: Dordrecht, The Netherlands, 2012. [CrossRef]

90. Drakopoulos, D.; Scholberg, J.M.S.; Lantinga, E.A.; Tittonell, P.A. Influence of reduced tillage and fertilization regime on crop performance and nitrogen utilization of organic potato. Org. Agric. 2016, 6, 75. [CrossRef]

91. Drakopoulos, D.; Scholberg, J.M.S.; Lantinga, E.A. Influence of reduced tillage and fertilisation regime on soil quality indicators in an organic potato production system. Biol. Agric. Hortic. 2018, 34, 132-140. [CrossRef]

92. Wilson, C.; Zebarth, B.J.; Burton, D.L.; Goyer, C.; Moreau, G.; Dixon, T. Effect of diverse compost products on potato yield and nutrient availability. Am. J. Potato Res. 2019, 96, 272-284. [CrossRef]

93. Davies, B.; Eagle, D.; Finney, B. Soil Management, 5th ed.; Farming Press: Ipswich, UK, 1993.

94. Mulder, A.; Turkensteen, L.J. Potato Diseases. Diseases, Pests and Defects; Aardappelwereld and NIVAP: The Hague, The Netherlands, 2005; 280p.

95. Czajkowski, R.; Pérombelon, M.C.M.; Van Veen, J.A.; Van der Wolf, J.M. Control of blackleg and tuber soft rot of potato caused by Pectobacterium and Dickeya species: A review. Plant. Pathol. 2011, 60, 999-1013. [CrossRef]

96. Dordas, C. Role of nutrients in controlling plant diseases in sustainable agriculture: A review. Agron. Sustain. Dev. 2008, $28,33-46$. [CrossRef]

97. Huber, D.; Römheld, V.; Weinmann, M. Relationship between nutrition, plant diseases and pests. In Mineral Nutrition of Higher Plants; Marschner, P., Ed.; Academic Press: Oxford, UK, 2012; pp. 283-298.

98. Sarwar, A.; Latif, Z.; Zhang, S.; Zhu, J.; Zechel, D.L.; Bechthold, A. Biological control of potato common scab with rare isatropolone C compound produced by plant growth promoting Streptomyces A1RT. Front. Microbiol. 2018, 9, 1126. [CrossRef] [PubMed]

99. Kirkegaard, J.; Sarwar, M. Biofumigation potential of brassicas. Plant. Soil 1998, 201, 71-89. [CrossRef]

100. Matthiessen, J.N.; Kirkegaard, J.A. Biofumigation and enhanced biodegradation: Opportunity and challenge in soilborne pest and disease management. Crit. Rev. Plant Sci. 2006, 25, 235-265. [CrossRef]

101. Ngala, B.M.; Haydock, P.J.; Wood, S.; Back, M.A. Biofumigation with Brassica juncea, Raphanus sativus and Eruca sativa for the management of field populations of the potato cyst nematode Globodera pallida. Pest. Manag. Sci. 2014, 71, 759-769. [CrossRef]

102. Vega-Âlvarez, C.; Francisco, M.; Soengas, P. Black rot disease decreases young Brassica oleracea plants' biomass but has no effect in adult plants. Agronomy 2021, 11, 569. [CrossRef]

103. Tein, B.; Kauer, K.; Runno-Paurson, E.; Eremeev, V.; Luik, A.; Selge, A.; Loit, E. The potato tuber disease occurrence as affected by conventional and organic farming systems. Am. J. Potato Res. 2015, 92, 662-672. [CrossRef]

104. Termorshuizen, A.J.; Van Rijn, E.; Van der Gaag, D.J.; Alabouvette, C.; Chen, Y.; Lagerlof, J.; Malandrakis, A.A.; Paplomatas, E.J.; Ramert, B.; Ryckeboer, J.; et al. Suppressiveness of 18 composts against 7 pathosystems: Variability in pathogen response. Soil Biol. Biochem. 2006, 38, 2461-2477. [CrossRef]

105. Bailey, K.L.; Lazarovits, G. Suppressing soil-borne diseases with residues management and organic amendments. Soil Tillage Res. 2003, 72, 169-180. [CrossRef]

106. Bernard, E.; Larkin, R.P.; Tavantzis, S.; Erich, M.S.; Alyokhin, A.; Gross, S.D. Rapeseed rotation, compost and biocontrol amendments reduce soilborne diseases and increase tuber yield in organic and conventional potato production systems. Plant. Soil 2014, 374, 611-627. [CrossRef] 
107. Moore, A.D.; Satterwhite, M.; Olsen, N.L.; Frazier, M.J. Russet Burbank potato response to repeated dairy manure applications in Kimberly, Idaho: Initial findings. In Proceedings of the Washington State Potato Conference, Kennewick, WA, USA, 26-28 January 2016. Available online: http:/ / www.nwpotatoresearch.com/ (accessed on 20 February 2021).

108. Deja-Sikora, E.; Kowalczyk, A.; Trejgell, A.; Szmidt-Jaworska, A.; Baum, C.; Mercy, L.; Hrynkiewicz, K. Arbuscular mycorrhiza changes the impact of Potato virus Y on growth and stress tolerance of Solanum tuberosum L. in vitro. Front. Microbiol. 2020, 10, 2971. [CrossRef]

109. Ball, B.C.; Bingham, I.; Rees, R.M.; Watson, C.A. The role of crop rotations in determining soil structure and crop growth conditions. Can. J. Plant. Sci. 2005, 85, 557-577. [CrossRef]

110. Karlen, D.L.; Hurley, E.G.; Andrews, S.S.; Cambardella, C.A.; Meek, D.W.; Duffy, M.D.; Mallarino, A.P. Crop rotation effects on soil quality at three northern corn/soybean belt locations. Agron. J. 2006, 98, 484-495. [CrossRef]

111. Larkin, R.P. Soil health paradigms and implications for disease management. Annu. Rev. Phytopathol. 2015, 53, 199-221. [CrossRef]

112. Larkin, R.P.; Honeycutt, C.W. Effects of different 3-year cropping systems on soil microbial communities and rhizoctonia diseases of potato. Phytopathology 2006, 96, 68-79. [CrossRef]

113. Larkin, R.P.; Griffin, T.S.; Honeycutt, C.W. Rotation and cover crop effects on soilborne potato diseases, tuber yield, and soil microbial communities. Plant. Dis. 2010, 94, 1491-1502. [CrossRef]

114. Snapp, S.S.; Date, K.U.; Kirk, W.; O’Neill, K.; Kremen, A.; Bird, G. Root, shoot tissues of Brassica juncea and Cereal secale promote potato health. Plant Soil 2007, 294, 55-72. [CrossRef]

115. Larkin, R.P. Green manures and plant disease management. CAB Rev. 2013, 8, 1-10. [CrossRef]

116. Cohen, M.F.; Mazzola, M.; Yamasaki, H. Brassica napus seed meal soil amendment modifies microbial community structure, nitric oxide production and incidence of Rhizoctonia root rot. Soil Biol. Biochem. 2005, 37, 1215-1227. [CrossRef]

117. Carter, M.R.; Sanderson, J.B. Influence of conservation tillage and rotation length on potato productivity, tuber disease and soil quality parameters on a fine sandy loam in eastern Canada. Soil Tillage Res. 2001, 63, 1-13. [CrossRef]

118. Brewer, M.T.; Larkin, R.P. Effects of microbial antagonists and a ryegrass rotation on rhizoctonia disease of potato. Phytopathology 2003, 94, S163.

119. Peters, R.D.; Sturz, A.V.; Carter, M.R.; Sanderson, J.B. Influence of crop rotation and conservation tillage practices on the severity of soil-borne potato diseases in temperate humid agriculture. Can. J. Soil Sci. 2004, 84, 397-402. [CrossRef]

120. Bonanomi, G.; Antignani, V.; Pane, C.; Scala, F. Suppression of soilborne fungal diseases with organic amendments. J. Plant. Pathol. 2007, 89, 311-324.

121. Wilson, P.S.; Ahvenniemi, P.M.; Lehtonen, M.J.; Kukkonen, M.; Rita, H.; Valkonen, J.P.T. Biological and chemical control and their combined use to control different stages of the Rhizoctonia disease complex on potato through the growing season. Ann. Appl. Biol. 2008, 153, 307-320. [CrossRef]

122. Wilson, P.S.; Ketola, E.O.; Ahvenniemi, P.M.; Lehtonen, M.J.; Valkonen, J.P.T. Dynamics of soil-borne Rhizoctonia solani in the presence of Trichoderma harzianum: Effects on stem canker, black scurf and progeny tubers of potato. Plant. Pathol. 2008, 57, 152-161.

123. Larkin, P.R. Relative effects of biological amendments and crop rotations on soil microbial communities and soilborne diseases of potato. Soil Biol. Biochem. 2008, 40, 1341-1351. [CrossRef]

124. Larkin, R.P.; Tavantzis, S. Use of biocontrol organisms and compost amendments for improved control of soilborne diseases and increased potato production. Am. J. Potato Res. 2013, 90, 261-270. [CrossRef]

125. Bera, R.; Seal, A.; Roy Chowdhury, R.; Datta, A.; Saha, S.; Sengupta, K. An innovative approach towards organic management of late blight in potato under Inhana rational farming technology. Res. Rev. J. Crop. Sci. Technol. 2017, 6, 13-24.

126. Aires, A.; Carvalho, R.; Barbosa, M.D.C.; Rosa, E. Suppressing potato cyst nematode, Globodera rostochiensis, with extracts of Brassicacea plants. Am. J. Potato Res. 2009, 86, 327-333. [CrossRef]

127. Henderson, D.R.; Riga, E.; Ramirez, R.A.; Wilson, J.; Snyder, W.E. Mustard biofumigation disrupts biological control by Steinernema spp. nematodes in the soil. Biol. Control. 2009, 48, 316-322. [CrossRef]

128. Mojtahedi, H.; Santo, G.S.; Hang, A.N.; Wilson, J.H. Suppression of root-knot nematode populations with selected rapeseed cultivars as green manure. J. Nematol. 1991, 23, 170-174.

129. Mojtahedi, H.; Santo, G.S.; Wilson, J.H. Host tests to differentiate Meloidogyne chitwoodi races 1 and 2 and M. hapla. J. Nematol. 1988, 20, 468-473.

130. Al-Rehiayani, S.; Hafez, S.L.; Thornton, M.; Sundararaj, P. Effects of Pratylenchus neglectus, Bacillus megaterium and oil radish or rapeseed green manure on reproductive potential of Meloidogyne chitwoodi on potato. Nematropica 1999, $29,37-49$.

131. Scholte, K.; Vos, J. Effects of potential trap crops and planting date on soil infestation with potato cyst nematodes and root-knot nematodes. Ann. Appl. Biol. 2000, 137, 153-164. [CrossRef]

132. Riga, E. The effects of Brassica green manures on plant parasitic and free living nematodes used in combination with reduced rates of synthetic nematicides. J. Nematol. 2011, 43, 119-121.

133. Engelbrecht, E.E. Nematode (Phylum Nematoda) Community Assemblages: A Tool to Implement Environmentally-Sound Management Strategies for Root-Knot Nematodes (Meloidogyne Spp.) in Potato-Based Cropping Systems. Ph.D. Thesis, NorthWest University, Potchefstroom, South Africa, 2012; 185p.

134. LaMondia, J.A. Management of lesion nematodes and potato early dying with rotation crops. J. Nematol. 2006, 38, 442-448. [PubMed] 
135. Larkin, R.P.; Honeycutt, C.W.; Olanya, O.M. Management of Verticillium wilt of potato with disease-suppressive green manures and as affected by previous cropping history. Plant. Dis. 2011, 95, 568-576. [CrossRef] [PubMed]

136. Escobedo-Monge, M.A.; Aparicio, S.; Escobedo-Monge, M.F.; Marugán-Miguelsanz, J.M. Long-term effects of the application of urban waste compost and other organic amendments on Solanum tuberosum L. Agronomy 2020, 10, 1575. [CrossRef]

137. Lombardo, S.; Abbate, C.; Pandino, G.; Parisi, B.; Scavo, A.; Mauromicale, G. Productive and physiological response of organic potato grown under highly calcareous soils to fertilization and mycorrhization management. Agronomy 2020, 10, 1200. [CrossRef]

138. Clark, M.S.; Horwath, W.R.; Shennan, C.; Scow, K.M.; Lantni, W.T.; Ferris, H. Nitrogen, weeds and water as yield-limiting factors in conventional, low-input, and organic tomato systems. Agric. Ecosyst. Environ. 1998, 73, 257-270. [CrossRef]

139. Offermann, F.; Nieberg, H. Economic performance of organic farms in Europe. In Organic Farming in Europe. Economics and Policy; Universität Hohenheim: Stuttgart, Germany, 2000; Volume 5.

140. Van Delden, A. Yield and growth components of potato and wheat under organic nitrogen management. Agron. J. 2001, 93, 1370-1385. [CrossRef]

141. Möller, K.; Habermeyer, J.; Zinkernagel, V.; Hans-Jürgen, R. Impact and interaction of nitrogen and Phytophthora infestans as yield-limiting and yield-reducing factors in organic potato (Solanum tuberosum L.) crops. Potato Res. 2007, 49, 281-301. [CrossRef]

142. Haase, T.; Schuler, C.; Hess, J. The effect of different $\mathrm{N}$ and $\mathrm{K}$ sources on tuber nutrient uptake, total and graded yield of potatoes (Solarium tuberosum L.) for processing. Eur. J. Agron. 2007, 26, 187-197. [CrossRef]

143. Lynch, D.H.; Sharifi, M.; Hammermeister, A.; Burton, D. Nitrogen management in organic potato production. In Sustainable Potato Production: Global Case Studies; He, Z., Larkin, R., Honeycutt, W., Eds.; Springer: Berlin/Heidelberg, Germany, 2012. [CrossRef]

144. Palmer, M.W.; Cooper, J.; Tétard-Jones, C.; Średnicka-Tober, D.; Barański, M.; Eyre, M.; Shotton, P.N.; Volakakis, N.; Cakmak, I.; Oztruk, L.; et al. The influence of organic and conventional fertilisation and crop protection practices, preceding crop, harvest year and weather conditions on yield and quality of potato (Solanum tuberosum) in a long-term management trial. Eur. J. Agron. 2013, 49, 83-92. [CrossRef]

145. Sharifi, M.; Lynch, D.H.; Zebarth, B.J.; Zheng, Z.; Martin, R.C. Evaluation of nitrogen supply rate measured by in situ placement of Plant Root Simulator ${ }^{\mathrm{TM}}$ probes as a predictor of nitrogen supply from soil and organic amendments in potato crop. Am. J. Pot Res. 2009, 86, 356-366. [CrossRef]

146. Nelson, K.L.; Lynch, D.H.; Boiteau, G. Assessment of changes in soil health throughout organic potato rotation sequences. Agric. Ecosyst. Environ. 2009, 131, 220-228. [CrossRef]

147. Hansen, J.G.; Koppel, M.; Valskyte, A.; Turka, I.; Kapsa, J. Evaluation of foliar resistance in potato to Phytophthora infestans based on an international field trial network. Plant Pathol. 2005, 54, 169-179. [CrossRef]

148. Razukas, A.; Jundulas, J.; Asakaviciute, R. Potato cultivars susceptibility to potato late blight (Phytophthora infestans). Appl. Ecol. Environ. Res. 2008, 6, 95-106. [CrossRef]

149. Mourão, I.; Brito, L.M.; Coutinho, J. Yield and quality of organic versus conventional potato crop. In Proceedings of the 16th IFOAM Organic World Congress, Modena, Italy, 16-20 June 2008. Available online: http:/ / orgprints.org/12660 (accessed on 10 March 2021).

150. De Ponti, T.; Rijk, B.; van Ittersum, M.K. The crop yield gap between organic and conventional agriculture. Agric. Syst. 2012, 108, 1-9. [CrossRef]

151. Asakaviciute, R.; Brazinskiene, V.; Razukas, A. Late blight Phytophtora infestans (Mont.) de Bary resistance evaluation in ten Lithuanian potato cultivars. Icel. Agric. Sci. 2013, 26, 45-48.

152. Lombardo, S.; Pandino, G.; Mauromicale, G. The influence of growing environment on the antioxidant and mineral content of early crop potato. J. Food Compos. Anal. 2013, 32, 28-35. [CrossRef]

153. Brazinskiene, V.; Asakaviciute, R.; Miezeliene, A.; Alencikiene, G.; Ivanauskas, L.; Jakstas, V.; Viskelis, P.; Razukas, A. Effect of farming systems on the yield, quality parameters and sensory properties of conventionally and organically grown potato (Solanum tuberosum L.) tubers. Food Chem. 2014, 145, 903-909. [CrossRef] [PubMed]

154. Kazimierczak, R.; Srednicka-Tober, D.; Hallmann, E.; Kopczynska, K.; Zarzynska, K. The impact of organic vs. conventional agricultural practices on selected quality features of eight potato cultivars. Agronomy 2019, 9, 799. [CrossRef]

155. Zarzyńska, K.; Pietraszko, M. Influence of climatic conditions on development and yield of potato plants growing under organic and conventional systems in Poland. Am. J. Potato Res. 2015, 92, 511-517. [CrossRef]

156. Ierna, A.; Parisi, B. Crop growth and tuber yield of "early" potato crop under organic and conventional farming. Sci. Hortic. 2014, 165, 260-265. [CrossRef]

157. Fiorillo, A.; Rouphael, Y.; Cardarelli, M.; Saccardo, F.; Colla, G.; Cirica, B. Yield and disease tolerance of potato cultivars grown under conventional and organic cultural management practices. Acta Hortic. 2005, 684, 79-83. [CrossRef]

158. Warman, P.R. Results of the long-term vegetable crop production trials: Conventional vs. compost-amended soils. Acta Hortic. 1998, 469, 333-340. [CrossRef]

159. Lombardo, S.; Pandino, G.; Mauromicale, G. The mineral profile in organically and conventionally grown early crop potato tubers. Sci. Hortic. 2014, 167, 169-173. [CrossRef]

160. Soltoft, M.; Nielsen, J.; Laursen, K.H.; Husted, S.; Halekoh, U.; Knuthsen, P. Effects of organic and conventional growth systems on the content of flavonoids in onions and phenolic acids in carrots and potatoes. J. Agric. Food Chem. 2010, 58, 10323-10329. [CrossRef] 
161. Dramicanin, A.M.; Andric, F.L.; Poštic, D.; Momirovic, N.M.; Milojkovic-Opsenica, D.M. Sugar profiles as a promising tool in tracing differences between potato cultivation systems, botanical origin and climate conditions. J. Food Compos. Anal. 2018, 72, 57-65. [CrossRef]

162. Vaitkevičienè, N.; Kulaitienè, J.; Jarienè, E.; Levickienè, D.; Danillčenko, H.; Średnicka-Tober, D.; Rembiałkowska, E.; Hallmann, E. Characterization of bioactive compounds in colored potato (Solanum tuberosum L.) cultivars grown with conventional, organic, and biodynamic methods. Sustainability 2020, 12, 2701. [CrossRef]

163. Keutgen, A.J.; Wszelaczynska, E.; Poberezny, J.; Przewodowska, A.; Przewodowski, W.; Milczarek, D.; Tatarowska, B.; Flis, B.; Keutgen, N. Antioxidant properties of potato tubers (Solanum tuberosum L.) as a consequence of genetic potential and growing conditions. PLoS ONE 2019, 14, e0222976. [CrossRef]

164. Bartova, V.; Diviš, J.; Barta, J.; Brabcova, A.; Svajnerova, M. Variation of nitrogenous components in potato (Solanum tuberosum L.) tubers produced under organic and conventional crop management. Eur. J. Agron. 2013, 49, 20-31. [CrossRef]

165. Diviš, J.; Bárta, J.; Heřmanová, V. Nitrogenous substances in potato (Solanum tuberosum L.) tubers produced under organic and conventional crop management. In Proceedings of the 3rd QLIF Congress: Improving Sustainability in Organic and Low Input Food Production Systems, Stuttgart, Germany, 20-23 March 2007.

166. Möller, K.; Reents, H.J. Impact of Agronomic Strategies (Seed Tuber Pre-Sprouting, Cultivars Choice) to Control Late Blight (Phytophtora infestans) on Tuber Growth and Yield in Organic Potato (Solanum tuberosum L.). Crops Potato Res. 2007, 50, 15-29. [CrossRef]

167. Lulai, E.C.; Orr, P.H. Influence of specific gravity on yield and oil content of chips. Am. Potato J. 1977, 56, 379-389. [CrossRef]

168. Dale, M.F.B.; Mackay, G.R.; Bradshaw, J.E. Inheritance of table and processing quality. In Potato Genetics; CAB International: Wallingford, UK, 1994; pp. 285-315.

169. Haase, N.U. Estimation of dry matter and starch concentration in potatoes by determination of under-water weight and near infrared spectroscopy. Potato Res. 2004, 46, 117-127. [CrossRef]

170. Cacace, J.E.; Huarte, M.A.; Monti, M.C. Evaluation of potato cooking quality in Argentina. Am. Potato J. 1994, 71, 145-153. [CrossRef]

171. Kirkman, M.A. Global markets for processed potato products. In Potato Biology and Biotechnology Advances and Perspectives; Vreugdenhil, D., Ed.; Elsevier: Amsterdam, The Netherlands, 2007; pp. 27-44. [CrossRef]

172. Herencia, J.F.; Garcia-Galavis, P.A.; Ruiz Dorado, J.A.; Maqueda, C. Comparison of nutritional quality of the crops grown in an organic and conventional fertilized soil. Sci. Hortic. 2011, 129, 882-888. [CrossRef]

173. Pither, R.; Hall, M.N. Analytical survey of the nutritional composition of organically grown fruit and vegetables. In Technical Memorandum No. 597, MAFF Project No. 4350; The Campden Food and Drink Research Association: Chipping Campden, UK, 1990; p. 31.

174. Burton, W.G. The Potato; Longman Sci and Tech.: London, UK, 1989.

175. Woolfe, J.A.; Poats, S.V. The Potato in the Human Diet; Cambridge University Press: Cambridge, UK, 1987.

176. Zommick, D.H.; Knowles, L.O.; Pavek, M.J.; Knowles, N.R. In-season heat stress compromises postharvest quality and lowtemperature sweetening resistance in potato (Solanum tuberosum L.). Planta 2014, 239, 1243-1263. [CrossRef]

177. Storey, M. The harvested crop. In Potato Biology and Biotechnology: Advances and Perspectives; Vreugdenhil, D., Bradshaw, J., Gebhardt, C., Govers, F., MacKerron, D.K.L., Taylor, M.A., Ross, H.A., Eds.; Elsevier: Oxford, UK, 2007; pp. 441-470.

178. Arvanitoyannis, I.S.; Vaitsi, O.; Mavromatis, A. Potato: A comparative study of the effect of cultivars and cultivation conditions and genetic modification on the physico-chemical properties of potato tubers in conjunction with multivariate analysis towards authenticity. Crit. Rev. Food Sci. Nutr. 2008, 48, 799-823. [CrossRef] [PubMed]

179. Muttucumaru, N.; Powers, S.J.; Elmore, J.S.; Mottram, D.S.; Halford, N.G. Effects of water availability on free amino acids, sugars, and acrylamide-forming potential inpotato. J. Agric. Food Chem. 2015, 63, 2566-2575. [CrossRef] [PubMed]

180. Coleman, W.K.; LeBlanc, J.; Morishita, T. A rapid test for chemical maturity monitoring of tubers. Am. Potato J. 1996, 73, 501-507. [CrossRef]

181. Leszkowiat, M.J.; Barichello, V.; Yada, R.Y.; Coffin, R.H.; Lougheed, E.C.; Stanley, D.W. Contribution of sucrose to non-enzymatic browning in potato chips. J. Food Sci. 1990, 55, 281-282. [CrossRef]

182. Ohara-Takada, A.; Matsuura-Endo, C.; Chuda, Y.; Ono, H.; Yada, H.; Yoshida, M.; Kobayashi, A.; Tsuda, S.; Takigawa, S.; Noda, T. Change in content of sugars and free amino acids in potato tubers under short-term storage at low temperature and the effect on acrylamide level after frying. Biosci. Biotechnol. Biochem. 2005, 69, 1232-1238. [CrossRef] [PubMed]

183. Struik, P.C.; Lommen, W.J.M.; Haverkort, A.J.; Stoyrey, R.M. The canon of potato science. Potato Res. 2007, 50, 205-206. [CrossRef]

184. Wang-Pruski, G. The canon of potato science: 47. After-cooking darkening. Potato Res. 2007, 50, 403. [CrossRef]

185. Wszelaki, A.L.; Delwiche, J.F.; Walker, S.D.; Liggett, R.E.; Scheerens, J.C.; Kleinhenz, M.D. Sensory quality and mineral and glycoalkaloid concentrations in organically and conventionally grown redskin potatoes (Solanum tuberosum). J. Sci. Food Agric. 2005, 85, 720-726. [CrossRef]

186. Hajšlová, J.; Schulzová, V.; Slanina, P.; Janné, H.K.; Andersson, K.E. Quality of organically and conventionally grown potatoes: Four-year study of micronutrients, metals, secondary metabolites, enzymic browning andorganoleptic properties. Food Addit. Contam. 2005, 22, 514-534. [CrossRef]

187. Rembiałkowska, E. Quality of plant products from organic agriculture. Review. J. Sci. Food Agric. 2007, 87, 2757-2762. [CrossRef] 
188. Wadas, W.; Dziugieł, T. Quality of new potatoes (Solanum tuberosum L.) in response to plant biostimulants application. Agriculture 2020, 10, 265. [CrossRef]

189. Grzeskiewicz, H.; Trawczynski, C. Foliar application of compound fertilizers in the potato cultivation. Folia Univ. Agric. Stetin. 1998, 190, 75-80.

190. Al-Bayaty, H.J.M.; Al-Quraishi, G.M.A. Response of three potato varieties to seaweed extract. Kufa J. Agric. Sci. $2019,11,36-48$.

191. Selim, E.M.; Mosa, A.A.; El-Ghamry, A.M. Evaluation of humic substances fertigation through surface and subsurface drip irrigation systems on potato growth under Egyptian sandy soil conditions. Agric. Water Manag. 2009, 96, 1218-1222. [CrossRef]

192. Canellas, L.P.; Olivares, F.L. Physiological responses to humic substances as plant growth promoter. Chem. Biol. Technol. Agric. 2014, 1, 3. [CrossRef]

193. Suh, H.Y.; Yoo, K.S.; Suh, S.G. Tuber growth and quality of potato (Solanum tuberosum L.) as affected by foliar or soil application of fulvic and humic acids. Hort. Environ. Biotechnol. 2014, 55, 183-189. [CrossRef]

194. Alenazi, M.; Wahb-Allah, M.A.; Abdel-Razzak, H.S.; Ibrahim, A.A.; Alsadon, A. Water regimes and humicacid application influences potato growth, yield, tuber quality and water use efficiency. Am. J. Potato Res. 2016, 93, 463-473. [CrossRef]

195. Conselvan, G.B.; Pizzeghello, D.; Francioso, O.; Di Foggia, M.; Nardi, S.; Carletti, P. Biostimulant activity of humic substances extracted from leonardities. Plant. Soil 2017, 420, 119-134. [CrossRef]

196. Ekin, Z. Integrated use of humic acid and plant growth promoting rhizobacteria to ensure higher potato productivity in sustainable agriculture. Sustainability 2019, 11, 3417. [CrossRef]

197. Tein, B.; Kauer, K.; Eremeev, V.; Luik, A.; Selge, A.; Loit, E. Farming systems affect potato (Solanum tuberosum L.) tuber and soil quality. Field Crops Res. 2014, 156, 1-11. [CrossRef]

198. Boligłowa, E.; Gleń, K. Yielding and quality of potato tubers depending on the kind of organic fertilization and tillage methods. Elec. J. Pol. Agroc. Univ. Ser. Agron. 2003, 1, 10-15.

199. Erhart, E.; Hartl, W.; Putz, B. Biowaste compost affects yield, nitrogen supply during the vegetation period and crop quality of agricultural crops. Eur. J. Agron. 2005, 23, 305-314. [CrossRef]

200. Lairon, D. Nutritional quality and safety of organic food a review. Agron. Sustain. Dev. 2009, 30, 33-41. [CrossRef]

201. Baranski, M.; Srednicka-Tober, D.; Volakakis, N.; Seal, C.; Sanderson, R.; Stewart, G.B.; Benbrook, C.; Biavati, B.; Markellou, E.; Giotis, C.; et al. Higher antioxidant and lower cadmium concentrations and lower incidence of pesticide residues in organically grown crops: A systematic literature review and meta-analyses. Br. J. Nutr. 2014, 112, 794-811. [CrossRef] [PubMed]

202. Camin, F.; Moshella, A.; Miselli, F.; Parisi, B.; Versini, G.; Ranalli, P.; Bagnaresi, P. Evaluation of the markers for the traceability of potato tuber grown in an organic and versus conventional regime. J. Sci. Food Agric. 2007, 87, 1330-1336. [CrossRef]

203. Montemurro, F.; Maiorana, M.; Lacertosa, G. Plant and soil nitrogen indicators and performance of tomato grown at different nitrogen fertilization levels. J. Food Agric. Environ. 2007, 5, 143-148.

204. Makaraviciute, A. Effect of organic and mineral fertilizers on the yield and quality of different potato varieties. Agron. Res. 2003, 1, 197-209.

205. Shepherd, L.V.T.; Hackett, C.A.; Alexander, C.J.; Sungurtas, J.A.; Pont, S.D.A.; Stewart, D.; McNicol, J.W.; Wilcockson, S.J.; Leifert, C.; Davies, H.V. Effect of agricultural production systems on the potato metabolome. Metabolomics 2014, 10, 212-224. [CrossRef]

206. Dixon, R.A.; Paiva, N.L. Stress-induced phenyl propanoid metabolism. Plant Cell 1995, 7, 1085-1097. [CrossRef]

207. Akula, R.; Ravishankar, G.A. Influence of abiotic stress signals on secondary metabolites in plants. Plant Signal. Behav. 2011, 6, 1720-1731. [CrossRef]

208. Ngadze, E.; Coutinho, T.A.; Icishayo, D.; van der Waals, J.E. Effect of calcium soil amendments on phenolic compounds and soft rot resistance in potato tubers. Crop Prot. 2014, 62, 40-45. [CrossRef]

209. Veberic, R. The impact of production technology on plant phenolics. Horticulturae 2016, 2, 8. [CrossRef]

210. Akyol, H.; Riciputi, Y.; Capanoglu, E.; Caboni, M.F.; Verardo, V. Phenolic compounds in the potato and its byproducts: An overview. Int. J. Mol. Sci. 2016, 17, 835. [CrossRef]

211. Galani, J.H.Y.; Mankad, P.M.; Shah, A.K.; Patel, N.J.; Acharya, R.R.; Talati, J.G. Effect of storage temperature on vitamin C, total phenolics, UPLC phenolic acid profile and antioxidant capacity of eleven potato (Solanum tuberosum) varieties. Hortic. Plant J. 2017, 3, 73-89. [CrossRef]

212. Smith-Spangler, C.; Brandeau, M.L.; Hunter, G.E.; Bavinger, J.C.; Pearson, M.; Eschbach, P.J.; Sundaram, V.; Liu, H.; Schirmer, P.; Stave, C.; et al. Are organic foods safer or healthier than conventional alternatives? A systematic review. Ann. Intern. Med. 2012, 157, 348-366. [CrossRef]

213. Friedman, M. Chemistry, biochemistry, and dietary role of potato polyphenols. A Review. J. Agric. Food Chem. 1997, 45, 1523-1540. [CrossRef]

214. Gumul, D.; Ziobro, R.; Noga, M.; Sabat, R. Characterization of five potato cultivars according to their nutritional and pro-health components. Acta Sci. Pol. Technol. Aliment. 2011, 10, 73-81.

215. Camire, M.E.; Kubow, S.; Donnelly, D.J. Potatoes and human health. Crit. Rev. Food Sci. Nutr. 2009, 49, 823-840. [CrossRef] [PubMed]

216. Mangge, H.; Becker, K.; Fuchs, D.; Gostner, J.M. Antioxidants, inflammation and cardiovascular disease. World J. Cardiol. 2014, 6, 462-477. [CrossRef] [PubMed]

217. Grudzińska, M.; Czerko, Z.; Zarzyńska, K.; Borowska-Komenda, M. Bioactive compounds in potato tubers: Effects of farming system, cooking method, and flesh color. PLoS ONE 2016, 11, e0153980. [CrossRef] [PubMed] 
218. Pinheiro, P.V.; Ghanim, M.; Alexander, M.; Rebelo, A.R.; Santos, R.S.; Orsburn, B.C.; Gray, S.M.; Cilia, M. Host plants indirectly influence plant virus transmission by altering gut cysteine protease activity of aphid vectors. Mol. Cell Proteom. 2017, 16, 230-243. [CrossRef] [PubMed]

219. Beals, K.A. Potatoes, Nutrition and Health. Am. J. Potato Res. 2019, 96, 102-110. [CrossRef]

220. Reddivari, L.; Vanamala, J.; Chintharlapalli, S.; Safe, S.H.; Miller, J. Anthocyanin fraction from potato extracts is cytotoxic to prostate cancer cells through activation of caspase-dependent and caspase-independent pathways. Carcinogenesis 2007, 28, 2227-2235. [CrossRef]

221. Nichenametla, S.N.; Taruscio, T.G.; Barney, D.L.; Exon, J.H.A. Review of the effects and mechanisms of polyphenolics in cancer. Crit. Rev. Food Sci. Nutr. 2006, 46, 161-183. [CrossRef] [PubMed]

222. Shih, P.H.; Yeh, C.T.; Yen, G.C. Effects of anthocyanin on the inhibition of proliferation and induction of apoptosis in human gastric adenocarcinoma cells. Food Chem. Toxicol. 2005, 43, 1557-1566. [CrossRef] [PubMed]

223. Stoner, G.D.; Chen, T.; Kresty, L.A.; Aziz, R.M.; Reinemann, T.; Nines, R. Protection against esophageal cancer in rodents with lyophilized berries: Potential mechanisms. Nutr. Cancer 2006, 54, 33-46. [CrossRef]

224. Jeon, T.W.; Cho, Y.S.; Lee, S.H.; Cho, S.M.; Cho, H.M.; Chang, K.S.; Park, H.J. Studies on the biological activities and physicochemical characteristics of pigments extracted from Korean purple-fleshed potato. Korean J. Food Sci. Technol. 2005, 37, $247-254$.

225. Hamouz, K.; Lachman, J.; Dvoøák, P.; Pivec, V. The effect of ecological growing on the potatoes yieldand quality. Plant Soil Environ. 2005, 51, 6.

226. Rodriguez-Saona, L.E.; Giusti, M.M.; Wrolstad, R.E. Anthocyanin pigment composition of red-fleshed potatoes. J. Food. Sci. 1998, 63, 458-465. [CrossRef]

227. Stratil, P.; Klejdus, B.; Kubán, V. Determination of total content of phenolic compounds and their antioxidant activity in vegetables evaluation of spectrophotometric methods. J. Agric. Food Chem. 2006, 54, 607-616. [CrossRef]

228. Burmeister, A.; Bondiek, S.; Apel, L.; Kühne, C.; Hillebrand, S.; Fleischmann, P. Comparison of carotenoid and anthocyanin profiles of raw and boiled Solanum tuberosum and Solanum phureja tubers. J. Food Comp. Anal. 2011, 24, 865-872. [CrossRef]

229. Jansen, G.; Flamme, W. Coloured potatoes (Solanum Tuberosum L.)-Anthocyanin content and tuber quality. Genet. Resour. Crop Evol. 2006, 53, 1321-1331. [CrossRef]

230. Tatarowska, B.; Milczarek, D.; Jakuczun, H.; Stochmal, A.; Pecio, Ł.; Flis, B. The potential for the improvement of carotenoids level in potato-Effect of the genotype and environment. J. Food Agric. Environ. 2014, 12, 536-540.

231. Romero-Pérez, A.I.; Lamuela-Raventós, R.M.; Andrés-Lacueva, C.; De La Carmen Torre-Boronat, M. Method for the quantitative extraction of resveratrol and piceid isomers in grape berry skins. Effect of powdery mildew on the stilbene content. J. Agric. Food Chem. 2001, 49, 210-215. [CrossRef] [PubMed]

232. Lachman, J.; Hanouz, K.; Šulc, M.; Orsák, M.; Pivec, V.; Hejtmánková, A.; Dvořák, P.; Čeplc, J. Cultivar differences of total anthocyains and anthocyanidins in red and purple-fleshed potatoes and their relation to antioxidant activity. Food Chem. 2009, 114, 836-843. [CrossRef]

233. Andre, C.M.; Oufir, M.; Guignard, C.; Homann, L.; Hausman, J.F.; Evers, D.; Larondelle, Y. Antioxidant profiling of native Andean potato tubers (Solanum tuberosum L.) reveals cultivars with high levels of $\beta$-carotene, $\alpha$-tocopherol, chlorogenic acid and petanin. J. Agric. Food Chem. 2007, 55, 10839-10849. [CrossRef] [PubMed]

234. Tierno, R.; Hornero-Méndez, D.; Gallardo-Guerrero, L.; López Pardo, R.; Ruiz de Galarreta, J.I. Effect of boiling on the total phenolic, anthocyanin and carotenoid concentrations of potato tubers from selected cultivars and introgressed breeding lines from native potato species. J. Food Compos Anal. 2015, 41, 58-65. [CrossRef]

235. Ezekiel, R.; Singh, N.; Sharma, S.; Kaur, A. Beneficial phytochemicals in potato are view. Food Res. Int. 2013, 50, 487-496. [CrossRef]

236. Gugała, M.; Zarzecka, K.; Sikorska, A.; Kapela, K.; Niewęłłowski, M.; Krasnodębska, E. Effect of soil conditioner (UGmax) application on the content of phenols and glycoalkaloids in potato tubers. Plant Soil Environ. 2017, 5, 231-235.

237. Leo, L.; Leone, A.; Longo, C.; Lombardi, D.A.; Raimo, F.; Zacheo, G. Antioxidant compounds and antioxidant activity in early potatoes. J. Agric. Food Chem. 2008, 56, 4154-4163. [CrossRef]

238. Navarre, D.A.; Shakya, R.; Hellmann, H. Vitamins, phytonutrients, and minerals in potato, chap. 6. In Advances in Potato Chemistry and Technology, 2nd ed.; Singh, J., Kaur, L., Eds.; Elseviser: Amsterdam, The Netherlands, 2016; pp. 117-166. [CrossRef]

239. Asami, D.K.; Hong, Y.J.; Barret, D.M.; Mitchell, A.E. Comparison of the total phenolic and ascorbic acid content of freeze-dried and air-dried marionberry, strawberry, and corn grown using conventional, organic, and sustainable agricultural practices. $J$. Agric. Food Chem. 2003, 51, 1237-1241. [CrossRef] [PubMed]

240. Wacholder, K.; Nehring, K. Über den Einfluß von Düngung und Boden auf den Vitamin C-Gehalt verschiedener Kartoffelsorten. 2. Mitt. Bodenk Pflanz. 1940, 16, 245-260. [CrossRef]

241. Storkova-Turnerova, J.; Prugar, J. Ehrnahrungsphysiologische Qualitat von okologisch und konventionell angebauten Kartoffelsorten in den Erntejahren 1994-1996. In Deutsche Gesellschaft fur Qualitetsforschung (Pfanzliche Lebensmittel); Schulz, H., Ed.; Vortragstagung: Dresden, Germany, 1998; Volume 33, pp. 209-215. (In German)

242. Brazinskiene, V.; Asakaviciute, R.; Razukas, A.; Ivanauskas, L. Quantification of biologically active compounds in the tubers of potato varieties of different maturity. Zemd. Agric. 2017, 104, 41-46. [CrossRef]

243. Dangour, A.D.; Dodhia, S.K.; Hayter, A.; Allen, E.; Lock, K.; Uauy, R. Nutritional quality of organic foods: A systematic review. Am. J. Clin. Nutr. 2009, 90, 680-685. [CrossRef] [PubMed] 
244. Muñoz, S.; Achaerandio, I.; Yang, Y.; Pujolà, M. Sous vide processing as an alternative to common cooking treatments: Impact on the starch profile, color, and shear force of potato (Solanum tuberosum L.). Food Bioprocess Technol. 2017, 10, 759-769. [CrossRef]

245. Asakaviciute, R.; Razukas, A. Potato (Solanum tuberosum L.) tubers sensory properties of different farming systems. Int. J. Agric. Environ. Bioresearch 2020, 5. [CrossRef]

246. Sinden, S.L.; Deahl, K.L.; Aulenbach, B.B. Effect of glycoalkaloids and phenolics on potato flavor. J. Food Sci. 1976, 41, 520-523. [CrossRef] 